\title{
Marine Macrolides with Antibacterial and/or Antifungal Activity
}

\section{Tomasz M. Karpiński}

Department of Medical Microbiology, Poznań University of Medical Sciences, Wieniawskiego 3, 61-712 Poznań, Poland; tkarpin@ump.edu.pl or tkarpin@interia.pl; Tel.: +48-61-854-61-38

Received: 16 March 2019; Accepted: 19 April 2019; Published: 23 April 2019

check for updates

\begin{abstract}
Currently, the increasing resistance of microorganisms to antibiotics is a serious problem. Marine organisms are the source of thousands of substances, which also have antibacterial and antifungal effects. Among them, marine macrolides are significant. In this review, the antibacterial and/or antifungal activities of 34 groups of marine macrolides are presented. Exemplary groups are chalcomycins, curvulides, halichondramides, lobophorins, macrolactins, modiolides, scytophycins, spongistatins, or zearalanones. In the paper, 74 antibiotics or their analog sets, among which 29 with antifungal activity, 25 that are antibacterial, and 20 that are both antifungal and antibacterial are summarized. Also, 36 macrolides or their sets are produced by bacteria, 18 by fungi, ten by sponges, seven by algae, two by porifera, and one by nudibranch. Moreover, the chemical structures of representatives from each of the 34 groups of these antibiotics are presented. To summarize, marine organisms are rich in natural macrolides. Some of these may be used in the future in the treatment of bacterial and fungal infections. Marine macrolides can also be potential drugs applicable against pathogens resistant to currently known antibiotics.
\end{abstract}

Keywords: macrolide; antibiotic; marine; antibacterial; antifungal; antimicrobial

\section{Introduction}

The marine world is rich in species and very diverse. Thus, marine organisms are a source of many substances with biological activity, including cytotoxic and antimicrobial. According to Burja et al., it was determined that in the marine world, there are over 13,000 unique compounds [1]. Important marine groups containing biologically active substances, including macrolides, are, among others, sponges [2] and cyanobacteria [3]. Swian et al. only described 121 compounds with antimicrobial activity among cyanobacteria, including the following chemical classes: alkaloids, aromatic compounds, pigments, fatty acids, phenols, macrolides, peptides, polyketides, porphinoids, and terpenoids [4]. Liu et al. described 118 marine macrolides, most with cytotoxic activity [5].

Macrolides are a group of polyketides. Currently, few of these substances are used in medicine. Among the antibacterial macrolides, the most important are erythromycin, azithromycin, roxithromycin, clarithromycin, josamycin, and spiramycin; among ketolides, telithromycin [6]. On the other hand, among antifungal polyene macrolides, amphotericin B, nystatin, and natamycin are most often used [7]. In general, antibacterial macrolides are active against Staphylococcus sp., Streptococcus sp., Neisseria gonorrhoea, Haemophilus influenzae, Bordetella pertussis, and Neisseria meningitis. Additionally, they are used in infections caused by intracellular pathogens, Mycoplasma sp. and Chlamydia sp. [8,9]. Clarithromycin is one of the antibiotics used in Helicobacter pylori infections [10]. The action of antibacterial macrolides is bacteriostatic. They reversibly bind to $23 \mathrm{~S}$ ribosomal RNA of the 50s subunit of the bacterial ribosome inhibiting RNA-dependent protein synthesis [11]. The antifungal macrolides bind to ergosterol and lead to pore formation, leakage of monovalent ions $\left(\mathrm{K}^{+}, \mathrm{Na}^{+}, \mathrm{H}^{+}\right.$and $\left.\mathrm{Cl}^{-}\right)$, and finally to fungal cell death [12]. 
Recently, the increasing resistance of bacteria to antibiotics has become a serious problem. Globally, about 700,000 deaths every year may be caused by microorganisms resistant to antimicrobials [13]. In epidemiology, the most significant are the multidrug-resistant bacteria, e.g., Escherichia coli, Klebsiella pneumoniae, Acinetobacter baumanii, methicillin-resistant Staphylococcus aureus (MRSA), vancomycin-resistant MRSA, penicillin-resistant Streptococcus pneumoniae (PRSP), vancomycin-resistant Enterococcus (VRE), and extensively drug-resistant (XDR) Mycobacterium tuberculosis [14]. Antimicrobial resistance is increasingly common among both human and animal pathogens [10,15-17]. Antimicrobial resistance related to food containing zoonotic and fecal bacteria (Salmonella sp., Campylobacter sp., Escherichia coli and Enterococcus sp.) is also gaining importance [18]. The hope is to find new antibiotics to fight against multidrug-resistant strains. The source of these drugs could be marine macrolides.

In this paper, literature regarding the structures and biological (antibacterial and antifungal) activities of marine macrolides was examined. This literature was found by searching for articles published in PubMed/MEDLINE using combinations of the following keywords: "marine", "macrolide/s", "antibacterial", "antifungal" and "antimicrobial". Titles and abstracts of the resulting papers were examined to exclude or include articles for review. From the references of the included articles, additional works were selected. Finally, ninety-four papers have been incorporated into this narrative review.

The antibacterial and/or antifungal activities of 34 groups of marine macrolides are presented in this review. Moreover, the chemical structures of representatives from each group of these antibiotics are also represented. The origin and biological target of marine macrolides are presented in Table.

\section{Antimicrobial Activity of Marine Macrolides}

\subsection{Macrolides 10-Membered}

\subsubsection{Curvulides}

Curvulides are compounds obtained from strains of the fungus Curvularia sp. From one strain associated with the red alga Acanthophora spicifera occurring in Fingers Reef, Apra Harbor and Guam, 10-membered lactones have been isolated: curvulide A (Figure 1a [19]), curvulide B1 and B2 [20]. Curvularin and (S)-dehydrocurvularin obtained from Curvularia sp. strain M12, showed activity against fungus-like Phytophthora capsici exhibited in zoospore motility disorder [21]. Curvularin stereoisomers additionally possess anti-inflammatory activity [22] and are cytotoxic toward human tumor cell lines [23]. The two 11-hydroxycurvularin isomers isolated from the marine actinomycete Pseudonocardia sp. HS7 obtained from the sea cucumber Holothuria moebii, showed antibacterial activity towards Escherichia coli [24]. It was demonstrated that curvularin and $\alpha \beta$-dehydrocurvularin have anti-fungal activity against Saccharomyces cerevisiae (minimum inhibitory concentration (MIC) $375-750 \mu \mathrm{g} / \mathrm{mL}$ ) and Sclerotinia sclerotiorum (MIC $>3000 \mu \mathrm{g} / \mathrm{mL}$ ). Both substances also inhibited the growth of Bacillus subtilis (MICs of 1500 and $>3000 \mu \mathrm{g} / \mathrm{mL}$ ), while $\alpha \beta$-dehydrocurvularin was additionally active against Staphylococcus aureus with an MIC of $375 \mu \mathrm{g} / \mathrm{mL}$. Presented macrolides were not active against Gram-negative bacteria such as Escherichia coli and Pseudomonas aeruginosa. Both compounds were produced by the fungus Eupenicillium sp. associated with marine sponge Axinella sp. collected in the South China Sea near Sanya, China [25]. Curvulalide, curvulapyrone, and an uncyclized modiolide macrolide, curvulalic acid isolated from a sea fan-derived Curvularia sp. PSUF22 were not active against Staphylococcus aureus ATCC 25923, methicillin-resistant S. aureus SK1, or Microsporum gypseum SHMU-4 [26].

\subsubsection{Modiolides}

To the 10-membered macrolides, belong modiolides A (Figure 1b) and B. Both are produced by fungus Paraphaeosphaeria sp. strain N-119, which was obtained from a marine horse mussel Modiolus auriculatus occurring in Hedo Cape, Japan. Modiolides A and B showed antibacterial activity 
against Micrococcus luteus (MIC $=16.7 \mathrm{mg} / \mathrm{mL}$ ) and antifungal activity against Neurospora crassa (MIC $=33.3 \mathrm{mg} / \mathrm{mL}$ ) [27]. Modiolide A is also the secondary metabolite of the marine-derived fungus Curvularia sp. Modiolide A and at least four substances resembling 10-membered lactones but featuring modified oxidation patterns around their macrocycles were shown to occur in this species [20]. In other studies, it was demonstrated that modiolide A obtained from Curvularia sp. strain M12, acts against the fungus-like eukaryotic microorganism Phytophthora capsici, leading to the disorder of zoospore motility at high concentrations $\left(\mathrm{IC}_{50}: 50-100 \mu \mathrm{g} / \mathrm{mL}\right.$ ) [21]. Trisuvan et al. showed a lack of modiolide A activity against strains Staphylococcus aureus ATCC 25923, methicillin-resistant S. aureus, and Microsporum gypseum SH-MU-4 at the initial concentration of $200 \mu \mathrm{g} / \mathrm{mL}$ [26].

\subsubsection{Phomolides}

Two 9-propyl-substituted 10-membered macrolides, phomolide A (Figure 1c) and B have been isolated from the marine fungus Phomopsis sp. hzla01-1. Both substances had significant activities against bacteria Escherichia coli CMCC44103, and fungi Candida albicans AS2.538 and Saccharomyces cerevisiae ATCC 9763 with MIC values of $5-10 \mathrm{mg} / \mathrm{mL}[28,29]$. Another similar chemical constituent, phomolide C, was obtained from the strain Phomopsis sp. B27 [30] and from the fungus Diaporthe sp., however it did not show antifungal activity against Cochliobolus miyabeanus [31].

\subsubsection{Xestodecalactones}

Xestodecalactones A-C, were obtained from an isolate of the fungus Penicillium cf. montanense from the marine sponge Xestospongia exigua collected from the Bali Sea, Indonesia. Among these metabolites, xestodecalactone B was found to have anti-fungal activity against the yeast Candida albicans at concentrations of $20 \mu \mathrm{M}$ and higher. Simultaneously, xestodecalactones A-C (Figure 1d) were inactive toward the bacteria Bacillus subtilis, Staphylococcus aureus, and Escherichia coli [32,33]. Xestodecalactones D-F obtained from Corynespora cassiicola, isolated from the Chinese mangrove plant Laguncularia racemosa, neither showed antibacterial nor antifungal activity [34].<smiles>C[C@@H]1CC[C@@H](O)C2O[C@H]2C=CC(=O)O1</smiles>

(a)<smiles>CCC[C@@H](C[C@@H]1O[C@H]1/C=C\C=C/C(=O)O)OC</smiles>

(c)<smiles>C[C@@H]1C[C@H](O)/C=C\C(O)=C/CC(=O)O1</smiles>

(b)<smiles>CC1C[C@H](O)CC(=O)c2c(O)cc(O)cc2CC1=O</smiles>

(d)

Figure 1. Chemical structures of 10-membered macrolides: (a) Curvulide A [19]; (b); Modiolide A [27]; (c) Phomolide A [28,29]; (d) Xestodecalactone B [33].

\subsection{Macrolides 12-Membered}

\subsubsection{Amphidinolides}

Amphidinolide $\mathrm{Q}$ (Figure 2a) and four analogs; amphidinins $\mathrm{C}-\mathrm{F}$, were isolated from the symbiotic dinoflagellate Amphidinium sp. The dinoflagellate Amphidinium sp. (2012-7-4A strain) was obtained from the marine acoel flatworm Amphiscolops sp. collected at Ishigaki Island, Okinawa, 
Japan. All compounds were active against Trichophyton mentagrophytes (MIC 16-32 $\mu \mathrm{g} / \mathrm{mL}$ ). Moreover, amphidinolide $\mathrm{Q}$ was active against $S$. aureus, B. subtilis, Escherichia coli, and Candida albicans (MICs $16-32 \mu \mathrm{g} / \mathrm{mL})$ [35].

\subsubsection{Dendrodolides}

Marine-derived Cladosporium fungi are a source of 12-membered macrolides dendrodolides A (Figure 2b), C, L, M and cladospolide B. Cladosporium sp. were cultivated from the gorgonian Anthogorgia ochracea obtained from the South China Sea. Three dendrodolides (A, C and M) showed antibacterial activity against Bacillus cereus, Tetragenococcus halophilus, Staphylococcus epidermidis, Staphylococcus aureus, Escherichia coli, Pseudomonas putida, Nocardia brasiliensis, and Vibrio parahaemolyticus, with MIC values ranging from 3.13 to $25.0 \mu \mathrm{M}$ [36].

\subsubsection{Lasiodiplodins}

Lasiodiplodins (Figure 2c) are resorcinolic macrolides [37] isolated among others from marine endophytic fungus No. ZZF36 connected with brown alga (Sargassum sp.). The fungus was collected from Zhanjiang Sea, China. Compound de-O-methyllasiodiplodin exhibited inhibitory activity against Staphylococcus aureus with an MIC of $6.25 \mu \mathrm{g} / \mathrm{mL}$, and lower activities against Bacillus subtilis, Salmonella enteritidis, Candida albicans and Fusarium oxysporum f.sp. cubense. Lasiodiplodin inhibited the growth of S. aureus, B. subtilis, and F. oxysporum (MICs 25-100 $\mu \mathrm{g} / \mathrm{mL}$ ), while 5-hydroxy-de-O-methyllasiodiplodin was shown to be only effective against $S$. aureus at $100 \mu \mathrm{g} / \mathrm{mL}$. Compound 6-oxo-de-O-methyllasiodiplodin was not active against all tested pathogens [38].

\subsubsection{Sporiolides}

Sporiolides are 12-membered macrocyclic lactones. Sporiolides A (Figure 2d) and B were isolated from the fungus Cladosporium sp., which was separated from a marine brown alga Actinotrichia fragilis (Okinawa Island, Japan). Both sporiolides were active against Micrococcus luteus with a MIC value of $16.7 \mu \mathrm{g} / \mathrm{mL}$. Moreover, sporiolide A showed antifungal activity against Aspergillus niger, Candida albicans, Cryptococcus neoformans, and Neurospora crassa with MICs of 8.4-16.7 $\mu \mathrm{g} / \mathrm{mL}$. Neither of the sporiolides were active against Bacillus subtilis, Escherichia coli, or Paecilomyces variotii [39,40].<smiles>C=C(CC)[C@H](C)C[C@@H](C[C@@H](C)C[C@@H](C)C(=O)C[C@@H](O)/C(C)=C/C(=O)O)OC</smiles>

(a)<smiles>COc1cc(O)cc(CCCCCCC[C@@H](C)O)c1C(=O)O</smiles>

(c)<smiles>[CH]C[C@@H](C)OC(=O)C[C@@H](O)/C=C/CC(=O)C[C@@H](CC(=O)O)OC</smiles>

(b)<smiles>CCCCC[C@H](C)OC(=O)C[C@@H]1OC(=O)[C@H](C)CCCCC[C@@H](O)C1=O</smiles>

(d)

Figure 2. Chemical structures of 12-membered macrolides: (a) Amphidinolide Q [35]; (b) Dendrodolide A [36]; (c) Lasiodiplodin [37]; (d) Sporiolide A [40]. 


\subsection{Macrolides 14-Membered}

\subsubsection{Lobophorins}

Lobophorins A (Figure 3a) and B were isolated from a marine Actinomycete strain \#CNB-837 isolated from the surface of the Caribbean brown alga Lobophora variegata [41,42]. Spirotetronate antibiotics; lobophorins E and F, were isolated from Streptomyces sp. SCSIO 01127 obtained from sediment in the South China Sea [40]. Lobophorins H and I were obtained from Streptomyces sp. strain 12A35, which was isolated from the deep-sea sediment of the South China Sea [43]. Lobophorins A, B, E, and F exhibited activities against Bacillus thuringensis SCSIO BT01 with MIC values of 2-8 $\mu \mathrm{g} / \mathrm{mL}$. Lobophorin F displayed antibacterial activities against Staphylococcus aureus ATCC 29213 and Enterococcus faecalis ATCC 29212 with MIC values of $8 \mu \mathrm{g} / \mathrm{mL}$ [43]. Additionally, lobophorins B, F, I and H exhibited inhibitory activities against Bacillus subtilis CMCC63501. Lobophorins B and $\mathrm{H}$ showed strong activities (MICs of $1.57-3.13 \mu \mathrm{g} / \mathrm{mL}$ ), while lobophorins $\mathrm{F}$ and I possessed moderate activities (MICs 6.25-50 $\mu \mathrm{g} / \mathrm{mL}$ ). Lobophorins $\mathrm{F}$ and $\mathrm{H}$ also had moderate activities against Staphylococcus aureus ATCC29213 with MIC values of 6.25-50 $\mu \mathrm{g} / \mathrm{mL}$. However, none of the studied compounds inhibited bacterium Escherichia coli, fungi Candida albicans or Fusarium moniliforme [44].

\subsubsection{Zearalanones}

$\beta$-resorcylic acid lactones were obtained from the culture of a Penicillium sp. derived from cotton clothing drifting off Namhae Island, which were zearalanone analogs: 8'-hydroxyzearalanone, 2 '-hydroxyzearalanol, zearalanone, $\beta$-zearalanol, zearalenone (Figure 3b), and $\beta$-zearalenol $[45,46]$. Some $\beta$-resorcylic macrolides were obtained from the marine Fusarium sp. O5ABR26 isolated from a sponge collected in the Miura Peninsula of Japan. Among these substances, zearalenone displayed the best inhibitory activity against fungus Pyricularia oryzae (MIC $6.25 \mu \mathrm{g} / \mathrm{mL}$ ). Simultaneously, $8^{\prime}$-hydroxyzearalenone was less active with a MIC value of $200 \mu \mathrm{g} / \mathrm{mL}$ [47]. It was demonstrated that fungus Fusarium sp. PSU-ES73, isolated from the seagrass Thalassia hemprichii found throughout the shores of the Indian and the Western Pacific Oceans, contains $\beta$-resorcylic macrolides 5 '-hydroxyzearalenone, zearalenone, $8^{\prime}$-hydroxyzearalenone, $7^{\prime}$-dehydrozearalenone, $\beta$-zearalenol, 5'-hydroxyzearalenol, and relgro. Only zearalenone exhibited weak activity against Staphylococcus aureus ATCC25923, methicillin-resistant S. aureus SK1 (MIC $400 \mu \mathrm{M}$ ), and Cryptococcus neoformans ATCC90113 (MIC $50.26 \mu \mathrm{M}$ ). The remaining compounds were inactive [48].

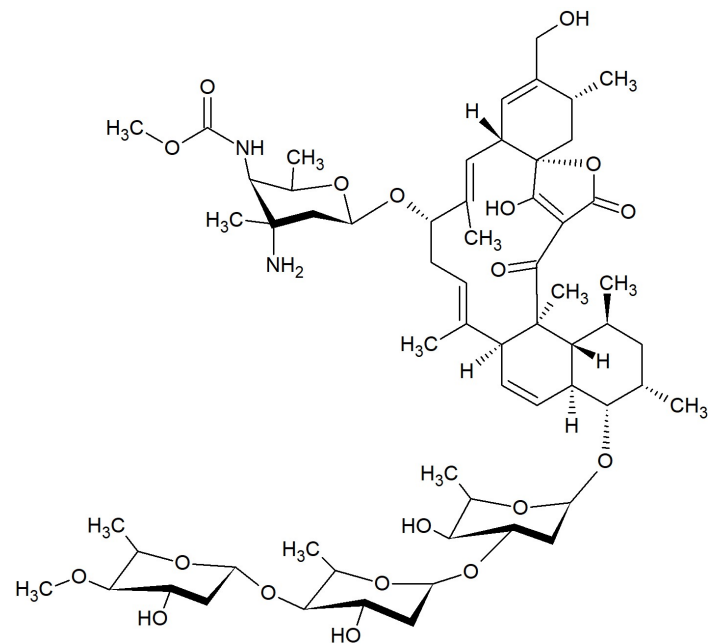

(a)<smiles>C[C@H]1CCCC(=O)CCC/C=C/c2cc(O)cc(O)c2C(=O)O1</smiles>

(b)

Figure 3. Chemical structures of 14-membered macrolides: (a) Lobophorin A [42]; (b) Zearalenone [46]. 


\subsection{Macrolides 15- and 16-Membered}

Bromophycolides

15- and 16-membered bromophycolides J-Q were isolated from extracts of the red alga Callophycus serratus from Yanuca, Fiji. Bromophycolides P (Figure $4 \mathrm{~b}$ ) and Q exhibited antibacterial activity against methicillin-resistant Staphylococcus aureus (MRSA) with an $\mathrm{IC}_{50}$ of 1.4 and $1.8 \mu \mathrm{M}$, respectively, and vancomycin-resistant Enterococcus faecium (VRE) with an $\mathrm{IC}_{50}$ of 13 and $5.8 \mu \mathrm{M}$, respectively [49].

\subsection{Macrolides 16-Membered}

\subsubsection{Butremycin}

Butremycin (Figure 4a) was isolated from Micromonospora sp. K310 obtained from mangrove river sediment in the Western Region of Ghana. Macrolide showed weak activity against Staphylococcus aureus ATCC 25923, Escherichia coli ATCC 25922 with a MIC of $50 \mu \mathrm{g} / \mathrm{mL}$ and some strains of methicillin-resistant $S$. aureus (MRSA) with a MIC $>50 \mu \mathrm{g} / \mathrm{mL}$ [50].

\subsubsection{Chalcomycins}

Chalcomycin A and chalcomycin B (Figure 4c) were isolated from the marine strain Streptomyces sp. B7064 derived from mangrove sediment near Pohoiki, Hawaii (Pacific Ocean). Both compounds exhibited excellent activities against bacteria Staphylococcus aureus (MIC $0.39 \mu \mathrm{g} / \mathrm{mL}$ ) and Bacillus subtilis (MIC $6.25 \mu \mathrm{g} / \mathrm{mL}$ ), and low activities against Escherichia coli (MIC $>50 \mu \mathrm{g} / \mathrm{mL}$ ). Chalcomycins did not show any activity towards fungi Candida albicans or Mucor miehei [51]. Dihydrochalcomycin, chalcomycin and chalcomycin E were isolated from marine-derived Streptomyces sp. HK-2006-1. Two compounds, dihydrochalcomycin and chalcomycin, exhibited activities against Staphylococcus aureus with MICs of 4-32 $\mu \mathrm{g} / \mathrm{mL}$ but were not active against Escherichia coli, Candida albicans, or Aspergillus niger [52].

\subsubsection{Neurymenolides}

Two $\alpha$-pyrone macrolides, neurymenolides A and B [53,54], were isolated from the red alga Neurymenia fraxinifolia collected from Taveuni, Fiji. Neurymenolide A (Figure 4d) possessed activity against methicillin-resistant Staphylococcus aureus with an $\mathrm{IC}_{50}$ of $2.1 \mu \mathrm{M}$ and vancomycin-resistant Enterococcus faecium with an $\mathrm{IC}_{50}$ of $4.5 \mu \mathrm{M}$ [53].

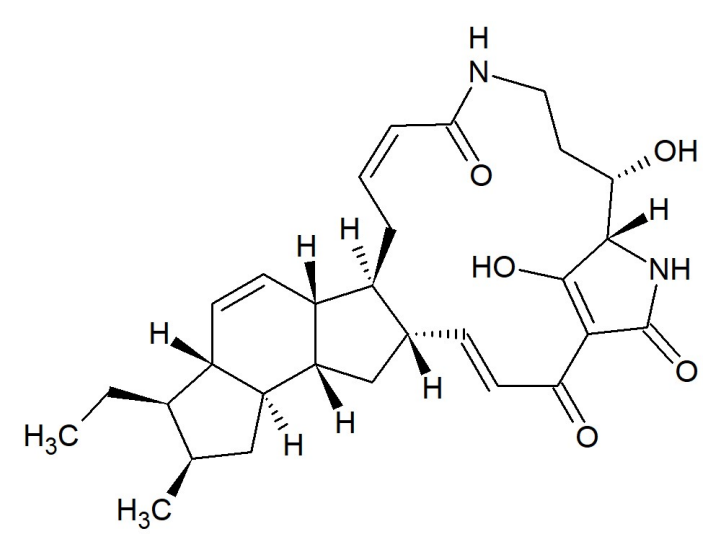

(a)<smiles>C=C1CCC(Br)C(C)(C)[C@H]1Cc1cc(C(=O)OC2CCC3(C)OC2(C)C[C@@H]3Br)ccc1O</smiles>

(b)

Figure 4. Cont. 


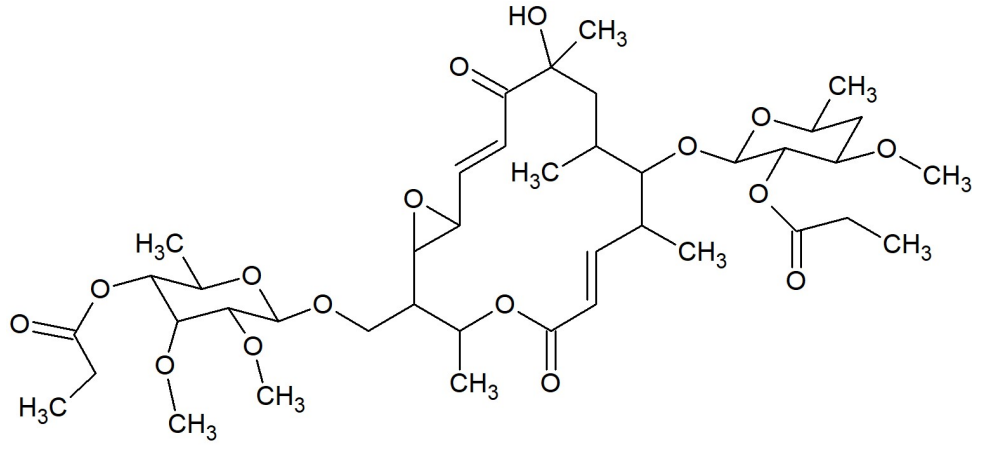

(c)

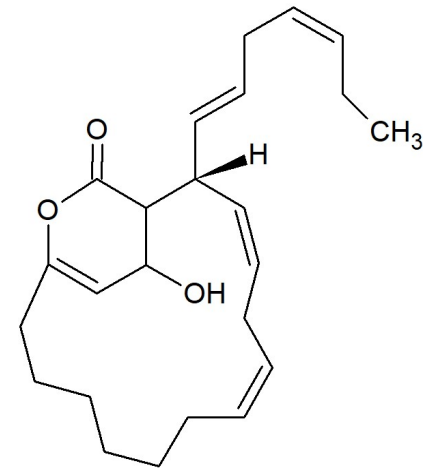

(d)

Figure 4. Chemical structures of 15- and 16-membered macrolides: (a) Butremycin [49]; (b) Bromophycolide P [50]; (c) Chalcomycin B [51]; (d) Neurymenolide A [53,54].

\subsection{Macrolides 18-Membered}

\subsubsection{Borrelidins}

Halophilic actinomycete Nocardiopsis sp. strain HYJ128 inhabiting a hypersaline saltern in Jeungdo, Jeollanam-do, Republic of Korea, produced 18-membered macrolides: borrelidin (Figure 5a) and borrelidins C-E. Borrelidin inhibited Enterococcus faecalis ATCC 19433, E. faecium ATCC 19434, Proteus hauseri NRBC 3851, Klebsiella pneumoniae ATCC 10031, and Salmonella enterica ATCC 14028 with MICs of 0.51-65 $\mu \mathrm{M}$. Borrelidins $C$ and D displayed inhibitory activity against S. enterica with MIC values of 16-63 $\mu \mathrm{M}$. Borrelidin E did not exhibit any inhibitory activity against the tested bacteria [55].

\subsubsection{Leucascandrolides}

Leucascandrolide A (Figure 5c) [56] was isolated from the calcareous sponge Leucascandra caveolata, collected along the east coast of the Coral Sea, New Caledonia. This compound strongly inhibited fungi Fusarium oxysporum, Helminthosporium sativum, Phytophthora hevea, Botrytis cinerea, Pyricularia oryzae, and yeast Candida albicans [57].

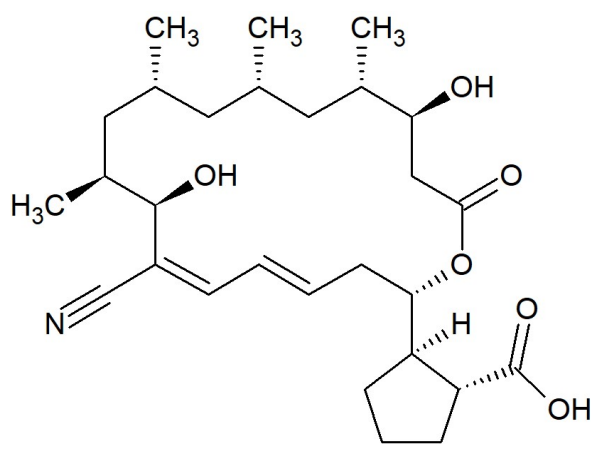

(a)

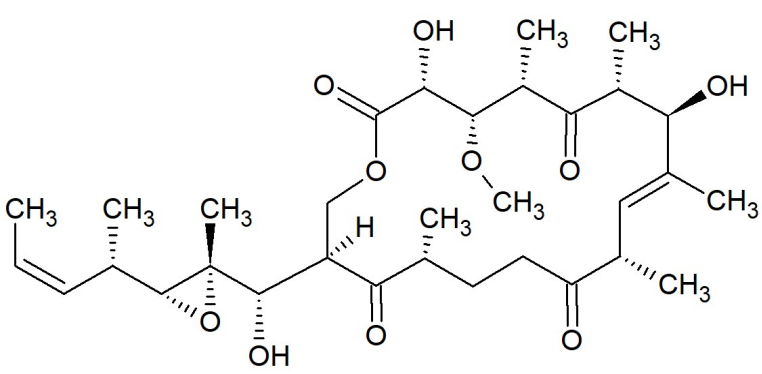

(b)

Figure 5. Cont. 


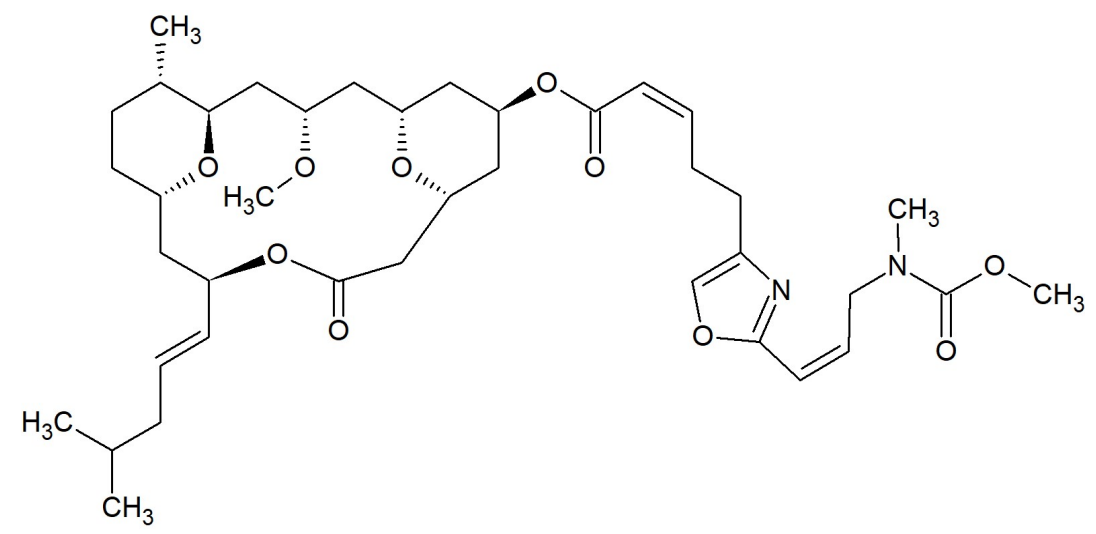

(c)

Figure 5. Chemical structures of 18-membered macrolides: (a) Borrelidin [55]; (b) 13-Deoxytedanolide [58,59]; (c) Leucascandrolide A [56].

\subsubsection{Tedanolides}

13-Deoxytedanolide (Figure $5 b$ ) is an 18-membered macrolide, which was isolated from the sponge Mycale adhaerens in Japan [58]. This macrolide strongly binds to the 60S large ribosomal subunit, causing inhibition of polypeptide elongation in fungus Saccharomyces cerevisiae, however it does not inhibit the polypeptide synthesis in bacterium Escherichia coli [59].

\subsection{Macrolides 20-Membered}

\subsubsection{Macrocyclic Polyesters}

The marine fungus Hypoxylon oceanicum (strain LL-15G256) from mangrove wood collected in Shenzhen, China, produced macrocyclic polyesters [60]. A 20-membered compound 15G256r (Figure 6a) exhibited low activity against the fungus Neurospora crassa acting as inhibitors of fungal cell wall formation. The 30-membered substance 15G256w had similar activity [61].<smiles>CC(Cc1cc(O)cc(O)c1C(=O)O)OC(=O)CC(C)OC(=O)c1c(O)cc(O)cc1CC(C)OC(=O)CC(C)OC(C)CC(=O)O</smiles>

(a)

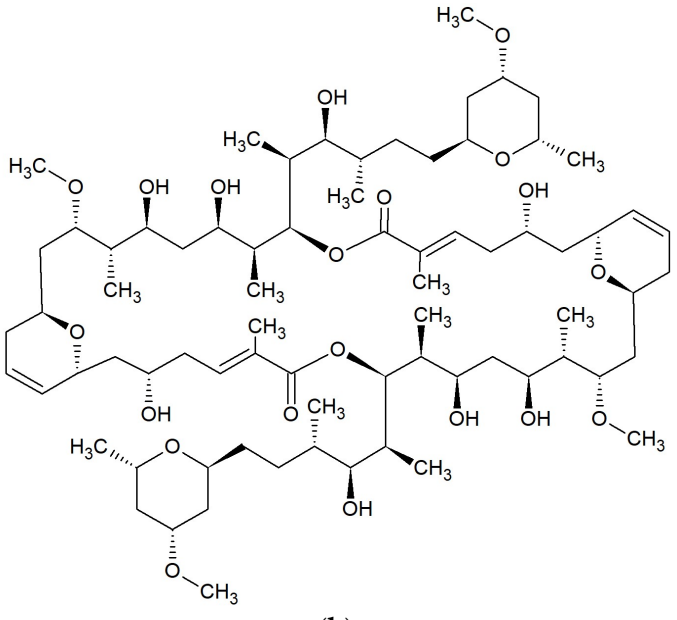

(b)

Figure 6. Chemical structures of 20-membered macrolides: (a) 15G256 [61]; (b) Misakinolide A [62,63].

\subsubsection{Misakinolides}

According to Sakai et al. misakinolide A (Figure 6b) is a 20-membered macrolide [62], however this macrolide occurs as 40-membered dimer [63]. Misakinolide A was isolated from the sponge Theonella sp., collected at Maeda-misaki, Okinawa, Japan. This compound possesses antifungal activity against Candida albicans (MIC $5 \mu \mathrm{g} / \mathrm{mL}$ ) [62]. 


\subsection{Macrolides 22-Membered}

\subsubsection{Kabiramides}

Kabiramide C (Figure 7a) was isolated from the eggmasses of an unidentified nudibranch collected at Kabira Bay on Ishigaki-jima Island of the Ryukyus Islands, Japan. This 22-membered macrolide showed marked antifungal activity against Candida albicans ATCC 10234, Aspergillus niger ATCC 9642, Penicillium citrium ATCC 9849 and Trichophyton interdigitale [64]. Kabiramides G, J and K were isolated from the sponge Pachastrissa nux collected in the Gulf of Thailand. These macrolides, together with kabiramides B-D, showed anti-parasite activity against Plasmodium falciparum K1 [65].

\subsubsection{Scytophycins}

Ishibashi et al. demonstrated that scytophycins A-E isolated from terrestrial blue-green alga Scytonema pseudohofmanni collected from Oahu, Hawaii, exhibited cytotoxicity and antifungal activity [66]. Scytophycin B, scytophycin E, 6-hydroxyscytophycin B, and tolytoxin (Figure 7b) (6-hydroxy-7-O-methylscytophycin B) obtained from the terrestrial blue-green alga Cylindrospermum muscicola, isolated on the island of Kauai, Hawaii also had antifungal activity [67]. Tolytoxin and two analogs; 6-hydroxyscytophycin B and 19-O-demethylscytophycin $\mathrm{C}$ were also produced by strains of Scytonema mirabile, S. burmanicum, and S. ocellatum. These macrolides had antifungal activity against Aspergillus oryzae, Candida albicans, Penicillium notatum, and Saccharomyces cerevisiae [68]. Tolytoxin isolated from blue-green alga Tolypothrix conglutinata var. colorata found at Fanning Island, Kiribati, exhibited additional inhibitory activity against Alternaria alternata, Bipolaris incurvata, Calonectria critalarae, Colletotrichum coccodes, Phyllosticta capitalensis, Phytophthora nicotianae, Rhizoctonia solani, Sclerotium rofsii, Thielaviopsis paradoxa, and Trichophyton mentagrophytes with MICs of $0.25-8 \mathrm{nM}$. Tolytoxin did not show any inhibitory activity against bacteria [69]. The presence of scytophycins with activity against Candida albicans and Aspergillus flavus has also been demonstrated in cyanobacteria Anabaena sp. HAN21/1, Anabaena cf. cylindrica PH133, Scytonema sp. HAN3/2, and Nostoc sp. HAN11/1 [70].

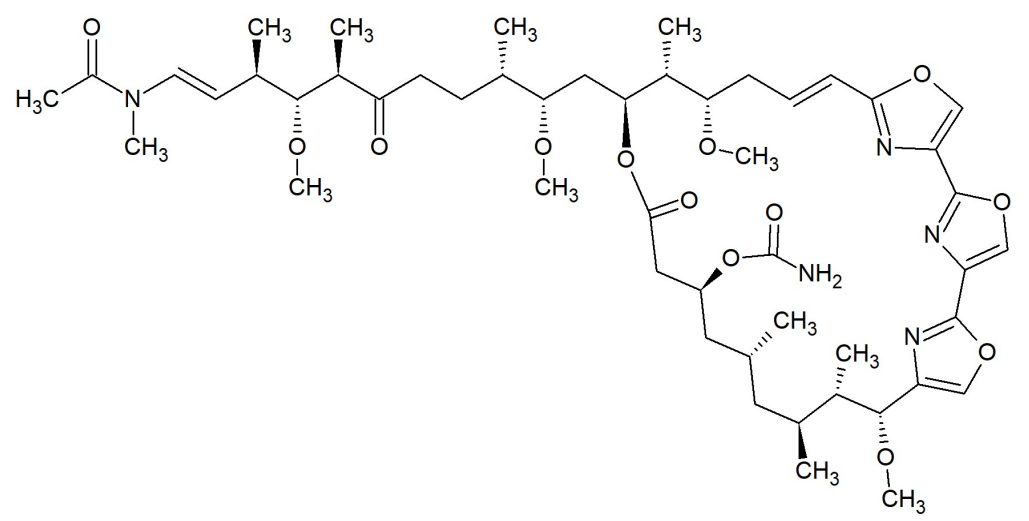

(a)

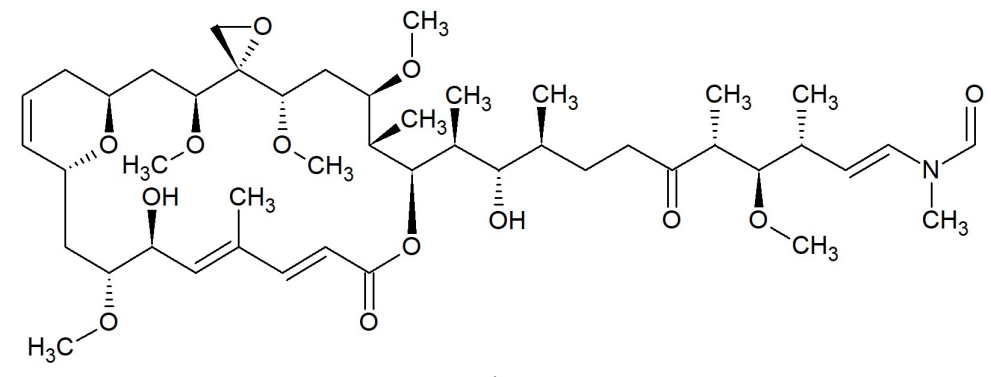

(b)

Figure 7. Chemical structures of 22-membered macrolides: (a) Kabiramide C [65]; (b) Tolytoxin [67]. 


\subsection{Macrolides 22-25-Membered}

\subsubsection{Gageomacrolactins}

Bacillus subtilis isolated from marine sediment collected from Gageocho, Republic of Korea, produced three gageomacrolactins (Figure 8a), which are 24-membered macrolactin derivatives. Gageomacrolactins displayed strong activity against some bacteria (Staphylococcus aureus, Bacillus subtilis, B. cereus, Escherichia coli, Salmonella typhi, and Pseudomonas aeruginosa) with MIC values of 0.02-0.05 $\mu \mathrm{M}$. Additionally, isolated gageomacrolactins and macrolactins A, B, F, and W inhibit the growth of Aspergillus niger, Botrytis cinerea, Colletotrichum acutatum, Candida albicans, and Rhizoctonia solani with MIC values of $0.04-0.3 \mu \mathrm{M}$ [71].

\subsubsection{Halichondramides}

An oxazole-containing macrolide, halichondramide (Figure 8b), is a 25-membered antibiotic [72]. It was obtained from the sponge Halichondria sp. from Kwajalein Island, Marshall Islands, and showed significant activity against Candida albicans (MIC $0.2 \mathrm{pg} / \mathrm{mL}$ ) and Trichophyton mentagrophytes (MIC $12.5 \mathrm{pg} / \mathrm{mL}$ ). Halichondramide did not inhibit bacteria [73]. Further studies revealed that the sponge of the genus Halichondria sp. also contains two other macrolides (dihydrohalichondramide and isohalichondramide) having significant activity against $C$. albicans. In this same paper, the authors showed that anti-C. albicans activity had the nudibranch Hexabranchus sanguineus, from which dihydrohalichondramide and tetrahydrohalichondramide were isolated [74]. From the marine sponge Chondrosia corticata collected from Guam, more oxazole-containing macrolides were isolated: neohalichondramide, (19Z)-halichondramide, and secohalichondramide. These compounds exhibited antifungal activity toward the Candida albicans and Aspergillus niger [75]. Chung et al. in the sponge C. corticata identified the following macrolides: halichondramide, jaspisamide A, halishigamide D, neohalichondramide, and (19Z)-halichondramide. None of the compounds were active against Gram-positive or Gram-negative bacteria at $100 \mu \mathrm{g} / \mathrm{mL}$. Halichondramide showed inhibitory activity against Candida albicans, Aspergillus fumigatus, Trichophyton rubrum, and T. mentagrophytes with MIC values of 0.2 to $0.91 \mu \mathrm{M}$. Compound (19Z)-halichondramide showed inhibitory activity against all tested fungi with MIC values of 0.78 to $14.55 \mu \mathrm{M}$. In the presented study, jaspisamide A, halishigamide $\mathrm{D}$, and neohalichondramide were inactive at $100 \mu \mathrm{g} / \mathrm{mL}$ [76].

\subsubsection{Macrolactins}

Macrolactins are a big group of 22- to 25-membered lactone macrolides. Some of these were isolated from a culture of Bacillus sp. PP19-H3 obtained from the macroalga Schizymenia dubyi collected on the Omaezaki coast of Shizuoka prefecture in Japan. Macrolactins A (Figure 8c), F, G, I, J, K, and L are 24-membered macrolides, macrolactin $\mathrm{H}$ is 22 -membered, and macrolactin is $\mathrm{M}$ a 25-membered lactone. Macrolactins A, G, H, I, J, L, and M were effective against Staphylococcus aureus (MICs 5-10 ppm), and Bacillus subtilis (MICs 30-60 ppm). The macrolactins F and $\mathrm{K}$ had low activity against the above bacteria (MICs 80 and $>100$ ). None of the studied macrolides inhibited Escherichia coli or Salinivibrio costicola $[77,78]$. In other studies, macrolactin A did not have any antimicrobial activity $[79,80]$.

Macrolactins A, B, F, and W isolated from marine Bacillus subtilis from Gageocho, Republic of Korea, inhibit the growth of Aspergillus niger, Botrytis cinerea, Colletotrichum acutatum, Candida albicans, and Rhizoctonia solani with MIC values of $0.04-0.3 \mu \mathrm{M}$ [71].

7-O-succinylmacrolactin $\mathrm{A}$ and 7-O-succinylmacrolactin $\mathrm{F}$, together with macrolactin $\mathrm{F}$, were isolated from the marine Bacillus sp. Sc026 occurring in sediments around Sichang Island, Thailand. These two succinylmacrolactins showed activity against Bacillus subtilis and Staphylococcus aureus [78]. 7-O-malonylmacrolactin A was isolated from soil B. subtilis from Takalar, South Sulawesi in Indonesia. This compound inhibited methicillin-sensitive S. aureus (MSSA), methicillin-resistant S. aureus (MRSA), vancomycin-resistant enterococci (VRE), Burkholderia cepacia, and Candida crusei $[79,80]$. 
Macrolactin N was obtained from Bacillus subtilis AT29 and had antibacterial activity against Escherichia coli, Staphylococcus aureus, and Bacillus subtilis. It inhibited the growth of E. coli with a MIC value of $100 \mu \mathrm{g} / \mathrm{mL}$, while for S. aureus and B. subtilis, the $\mathrm{MIC}_{50}$ is $100 \mu \mathrm{g} / \mathrm{mL}$. Macrolactin N inhibited S. aureus peptide deformylase with an $\mathrm{IC}_{50}$ value of $7.5 \mu \mathrm{M}$ [81].

From the marine Bacillus sp. derived from the sea sediment of East China Sea, macrolactin $\mathrm{S}$, a 24-membered ring lactone, was obtained. Macrolactin S, together with macrolactins A and B had antibacterial activity against Escherichia coli, and Staphylococcus aureus [82].

Macrolactins $\mathrm{T}$ and $\mathrm{U}$, along with macrolactins $\mathrm{A}, \mathrm{B}, \mathrm{D}, \mathrm{O}$, and $\mathrm{S}$, were isolated from the bacterium Bacillus marinus, which was separated from Suaeda salsa collected in the coastline of the Bohai Sea of China. In the study, authors reported the inhibitory activity of macrolactins B (MIC 4.5-20.1 $\mu \mathrm{g} / \mathrm{mL}$ ) and $\mathrm{D}(\mathrm{MIC}>100 \mu \mathrm{g} / \mathrm{mL}$ ) against fungi Pyricularia oryzae and Alternaria solani, and bacterium Staphylococcus aureus [83].

From marine bacterium B. amyloliquefaciens SCSIO 00856 isolated from the South China Sea gorgonian Junceella juncea, macrolactin V and S. Macrolactin V were obtained and had strong antibacterial activities against Escherichia coli, Bacillus subtilis, and Staphylococcus aureus with a MIC value of $0.1 \mu \mathrm{g} / \mathrm{mL}$. Macrolactin S showed potent activity against E. coli and S. aureus (MICs $0.1-0.3 \mu \mathrm{g} / \mathrm{mL}$ ), and weak against B. subtilis (MIC $100 \mu \mathrm{g} / \mathrm{mL}$ ) [84].

Macrolactin W was isolated from a marine Bacillus sp. 09ID194 collected from Ieodo, a southern reef of South Korea. This macrolide showed antibacterial activities towards Bacillus subtilis, Staphylococcus aureus, Escherichia coli, and Pseudomonas aeruginosa with a MIC of $64 \mu \mathrm{g} / \mathrm{mL}$ [85].

One of the marine Bacillus sp. produces three 24-membered macrolactins, which contain an oxetane, an epoxide, and a tetrahydropyran ring, respectively. All three macrolactins showed antimicrobial activity against Bacillus subtilis and Escherichia coli (MIC $0.16 \mu \mathrm{M})$. The macrolactin with an epoxide ring also had excellent activity against Saccharomyces cerevisiae (MIC 0.02-0.16 $\mu \mathrm{M}$ ) [86].

From Bacillus subtilis MTCC 10403, isolated from the brown seaweed Anthophycus longifolius collected from the Gulf of Mannar of India, new antimicrobial aryl-crowned polyketide macrolactin was obtained. This substance had bactericidal properties against Escherichia coli, Aeromonas hydrophilla, Pseudomonas aeruginosa, and Vibrio sp. at a low concentration with $\mathrm{MIC}<13 \mu \mathrm{g} / \mathrm{mL}$, and against Klebsiella pneumoniae with MIC $\sim 25 \mu \mathrm{g} / \mathrm{mL}$. The mode of antimicrobial action of this new acryl-crowned macrolactin was found to be iron chelating similar to siderophores [87].

\subsubsection{Maduralide}

Maduralide (Figure 8d) is 24-membered ring macrolide. It was isolated from an unidentified marine bacterium of the order Actinomycetales in the shallow waters of Bodega Bay, USA. Maduralide shows weak antibiotic activity against Bacillus subtilis [88].

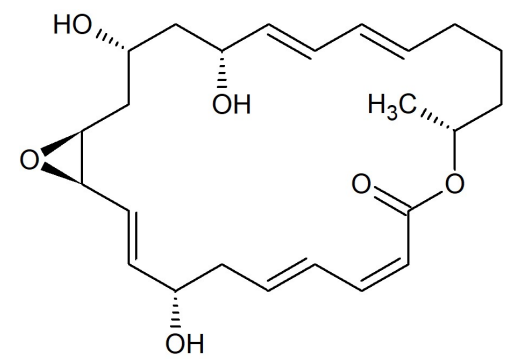

(a)

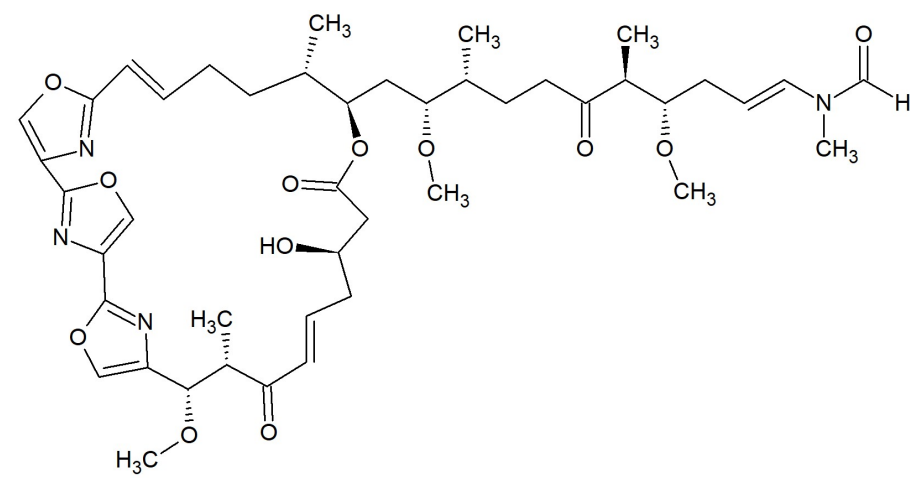

(b)

Figure 8. Cont. 
<smiles></smiles>

(c)<smiles>CCC(O)C(C)C1OC(=O)CC(O)C(C)C1C/C=C/C(=O)C(C)CC(C)C(O[C@@H]1O[C@H](C)[C@@H](O)[C@H](OC)[C@H]1O)C(C)/C=C\C(=O)C(C)/C=C(\C)C(=O)C(C)C</smiles>

(d)

Figure 8. Chemical structures of 22-25-membered macrolides: (a) Gageomacrolactin 1 [71]; (b) Halichondramide [72]; (c) Macrolactin A [77,78]; (d) Maduralide [88].

\subsection{Macrolides 26-Membered}

\subsubsection{Neomaclafungins}

Neomaclafungins A-I (Figure 9a) were produced by the bacteria Actinoalloteichus sp. NPS702 isolated from the marine sediment of Usa Bay, Kochi Prefecture, Japan. These oligomycin macrolides exhibited significant antifungal activity in vitro against Trichophyton mentagrophytes ATCC 9533, with MIC values of $1-3 \mu \mathrm{g} / \mathrm{mL}$ [89].

\subsubsection{Phorboxazoles}

Phorboxazoles A (Figure 9b) and B were isolated from the Indian Ocean marine sponge Phorbas sp. Both antibiotics had antifungal activity against Candida albicans and Saccharomyces carlsbergensis. None of these compounds showed any activity against Escherichia coli, Pseudomonas aeruginosa, or Staphylococcus aureus [90].

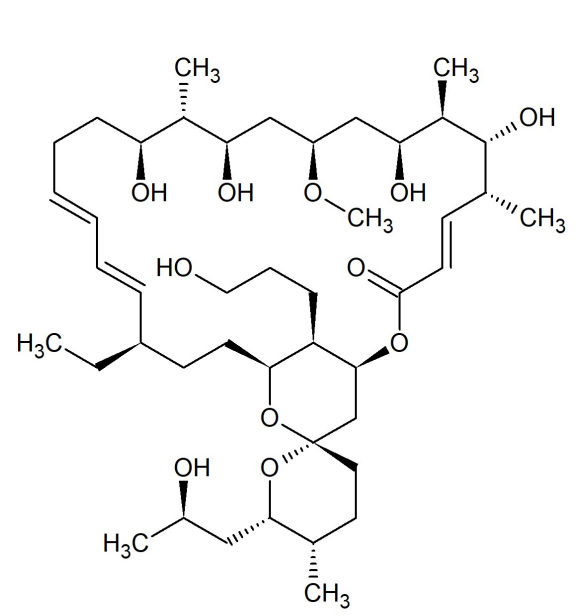

(a)

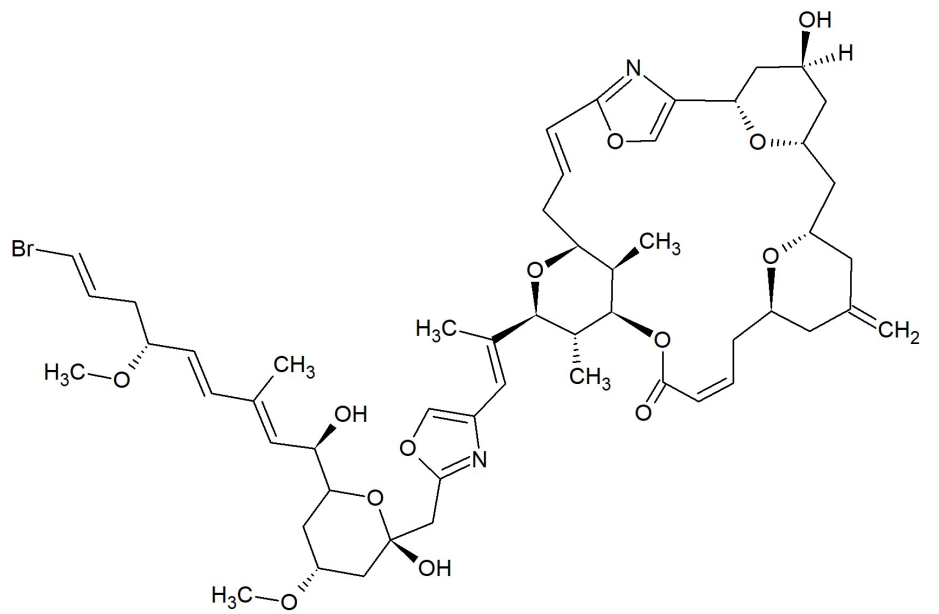

(b)

Figure 9. Chemical structures of 26-membered macrolides: (a) Neomaclafungin A [89]; (b) Phorboxazole A [90].

\subsection{Macrolides 31-Membered}

\section{Reedsmycins}

Reedsmycins are nonglycosylated polyene-polyol macrolides produced by marine-derived Streptomyces youssoufiensis OUC6819 [91] and by Streptomyces sp. CHQ-64 [92]. Reedsmycin A (Figure 10a) exhibited antifungal activity against Candida albicans (MIC 25-50 $\mu \mathrm{M}$ ). Other compounds 
in this group had lower activity. MICs for reedsmycins C-E were $50-100 \mu \mathrm{M}$, for reedsmycin B were 100-200 $\mu$ M. Reedsmycin F exhibited no inhibitory activity [92].

\subsection{Macrolides 34-Membered}

Marinisporolides

Two polyene-polyol macrolides; marinisporolides A (Figure 10b) and B were isolated from the marine actinomycete Marinispora strain CNQ-140, collected offshore from La Jolla, California, USA. Both marinisporolides showed weak or no antifungal activity against Candida albicans with a MIC value of $22 \mu \mathrm{M}$ [93].<smiles>CCC(C)/C=C/C(O)CC(O)CC(O)CC(O)CC(O)CC(O)CC(O)CC(O)C/C=C/C=C/C=C/C=C/C=C/C(=O)OC(C(C)CC)C(C)CC</smiles>

(a)

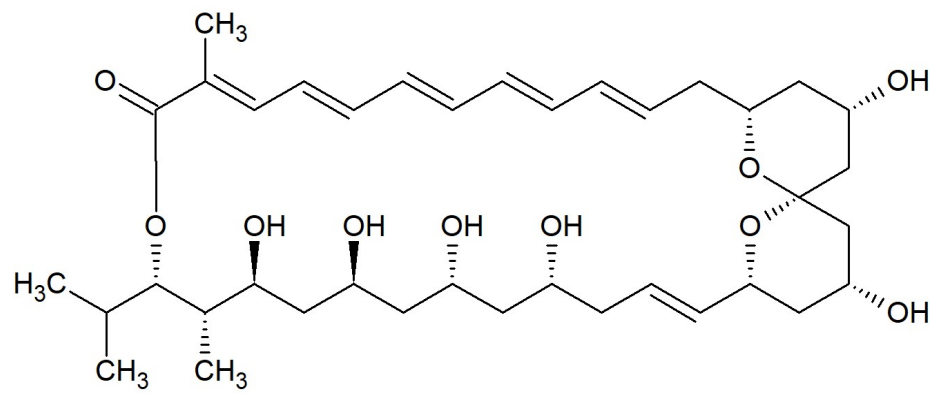

(b)

Figure 10. Chemical structures of 31-membered macrolide: (a) Reedsmycin A [92]; and 34-membered macrolide: (b) Marinisporolide A [93].

\subsection{Macrolides 36-Membered}

\subsubsection{Azalomycins}

Two macrocyclic lactones, azalomycin F4a 2-ethylpentyl ester and azalomycin F5a 2-ethylpentyl ester, were identified from metabolites of Streptomyces sp. 211726 isolated from mangrove rhizosphere soil of Heritiera globosa collected in Wenchang, China. Both compounds showed moderate activity against Candida albicans ATCC 10231 at the MICs of 2.34 and $12.5 \mu \mathrm{g} / \mathrm{mL}$ [94]. Seven analogs of azalomycin F (Figure 11a) were identified from this strain with the same fermentation condition and showed antimicrobial activity against C. albicans ATCC 10231 (MICs 1.56-6.25 $\mu \mathrm{g} / \mathrm{mL}$ ), Staphylococcus

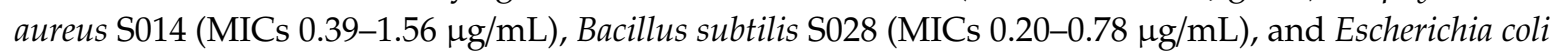
S002 (MICs 3.13-25.00 $\mu \mathrm{g} / \mathrm{mL}$ ) [95].

\subsubsection{Bahamaolides}

From the marine actinomycete Streptomyces sp. CNQ343 derived from sediment collected at North Cat Cay in the Bahamas, bahamaolides A and B. Bahamaolide A (Figure 11b) displaying significant inhibitory activity against Candida albicans ATCC 10231 with a MIC value of $12.5 \mu \mathrm{g} / \mathrm{mL}$ acting on enzyme isocitrate lyase were isolated. It also possessed antifungal activity against various pathogenic fungi: Aspergillus fumigatus HIC 6094, Trichophyton rubrum IFO 9185, T. mentagrophytes IFO4 0996. Bahamaolide B did not inhibit any tested strain [96]. 


\subsubsection{Polyhydroxyl Macrolides}

Two polyhydroxyl macrolide lactones, PM100117 (Figure 11c) and PM100118 were isolated from the marine actinobacteria Streptomyces caniferus GUA-06-05-006A. Both substances possessed antifungal activity against Candida albicans ATCC10231 [97]. PM100117 also showed antibiotic activity against Saccharomyces cerevisiae W303.1A but was not active towards Micrococcus luteus [98].

\subsection{Macrolides 40-Membered}

\section{Amantelides}

Amantelides A (Figure 11d) and B were isolated from gray cyanobacterium belonging to the family Oscillatoriales, collected near Puntan dos Amantes, Tumon Bay, Guam. The antifungal activity of amantelide A was observed against the marine fungi Dendryphiella salina, Lindra thalassiae, and Fusarium sp. at a concentration of $62.5 \mu \mathrm{g} / \mathrm{mL}$. Moreover, macrolide had weak antibacterial activity against Staphylococcus aureus and Pseudomonas aeruginosa with a MIC of $32 \mu \mathrm{M}$. Amantelide B inhibited the growth of Dendryphiella salina at a concentration of $6.25 \mu \mathrm{g} / \mathrm{mL}$ [99].

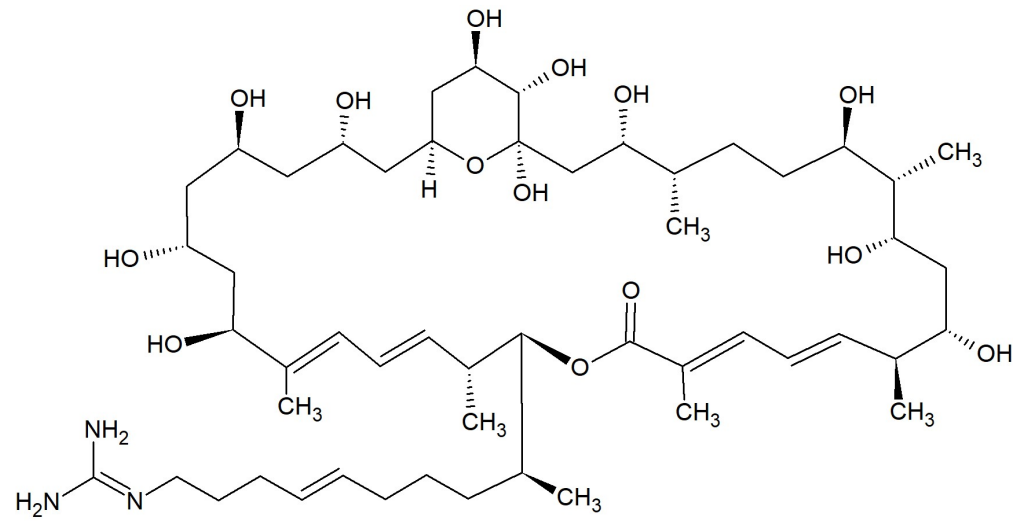

(a)<smiles>CC(C)CC[C@H](O)C[C@H](O)C[C@H](O)C[C@H](O)C[C@H](O)C[C@H](O)C[C@H](O)C[C@H](O)C[C@H](O)C/C=C/C=C/C=C/C=C/C=C/C=C/C(=O)OC(C(C)C)C(C)C</smiles>

(b)<smiles>CCC(OC1CC(C)(O)C(OC2CC(O)C(OC(=O)C(C)C(OC3CCC(O)C(C)O3)c3ccc4c(c3)C(=O)C=C(C)C4=O)C(C)O2)C(C)O1)C(C)C(O)C(C)C(O)C(C)C(OC(=O)/C=C/CC(O)CC(O)CCCC(O)CCC(C)C(O)C(=O)C12CC(O)CC(CC(O)CC(O)CC(O)CCCC(O)C=CC1O)O2)C(C)/C=C/C(O)CC(O)CC(C)C</smiles>

(c)

Figure 11. Cont. 


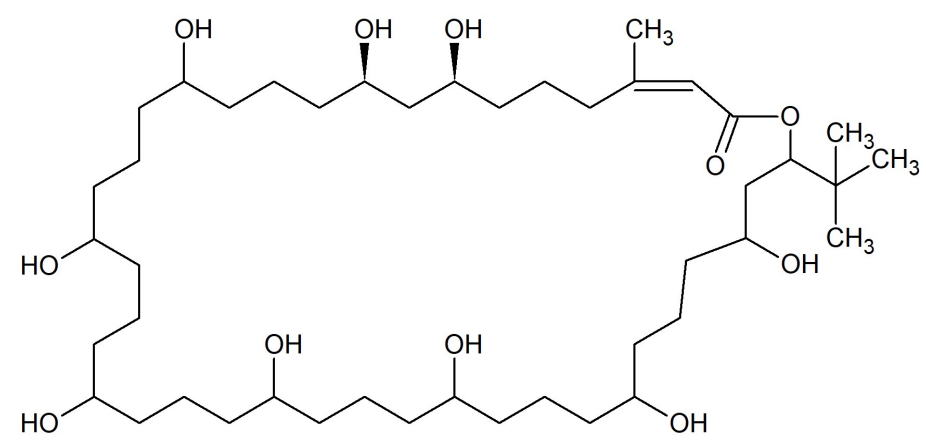

(d)

Figure 11. Chemical structures of 36-membered macrolides: (a) Azalomycin F [95]; (b) Bahamaolide A [96]; (c) PM100117 [97]; and 40-membered macrolide: (d) Amantelide A [99].

\subsection{Macrolides 42-Membered}

Spongistatins

The spongistatins are macrocyclic lactone polyethers isolated from marine porifera. Spongistatin 1 (Figure 12) was discovered in an Indian Ocean Spongia species [100] and Hyrtios erecta together with spongistatins 2 and 3 [101]. Spongistatins 4-7 were obtained from the southeast African Spirastrella spinispirulifera [102,103]. All of these antibiotics inhibited the growth of Candida albicans and Cryptococcus neoformans in disk diffusion assays. Furthermore, Spongistatin 1 acted against Issatchenkia orientalis, Rhodotorula mucilaginosa, Aspergillus fumigatus, and Rhizopus oligosporus with MICs of $0.195-12.5 \mu \mathrm{g} / \mathrm{mL}$ [104].

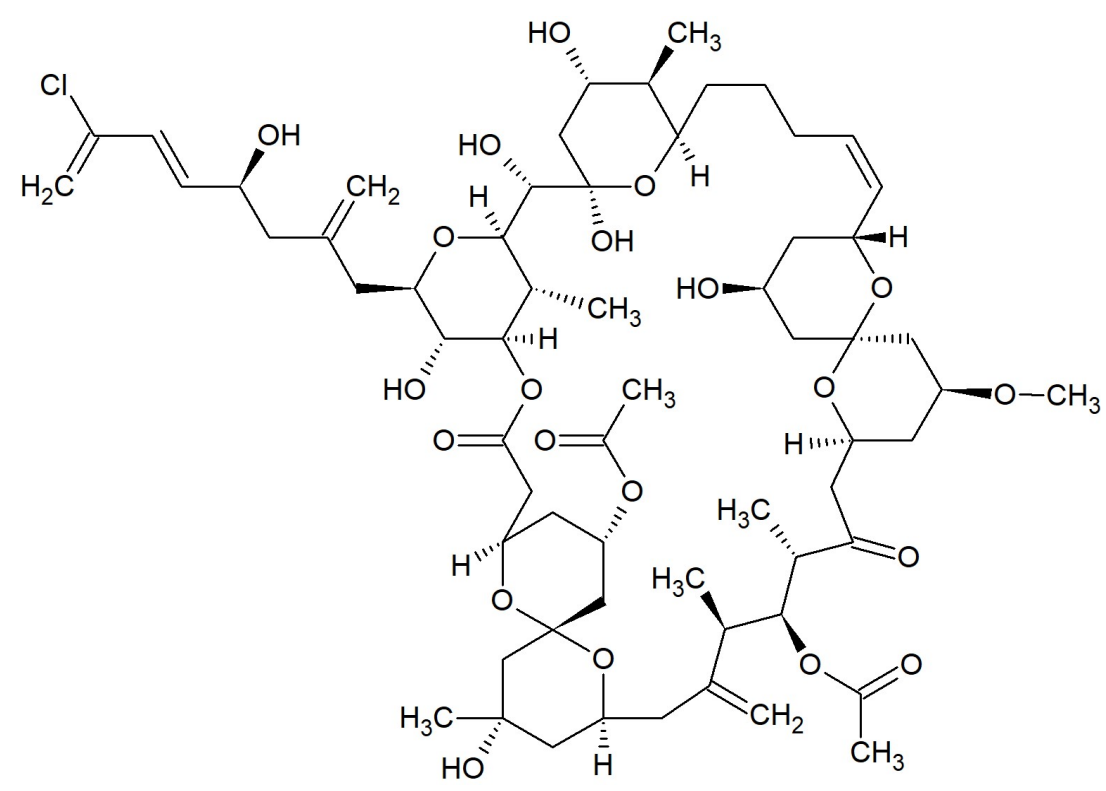

Figure 12. Chemical structure of 42-membered macrolide: Spongistatin 1 [100].

In Table 1 has been presented the general characteristic of marine macrolides described in this review. 
Table 1. The general characteristic of marine macrolides having antimicrobial activity.

\begin{tabular}{|c|c|c|c|c|}
\hline No. & Macrolide & Source & Target & References \\
\hline 1 & (19Z)-halichondramide & sponge Chondrosia corticata & $\begin{array}{l}\text { Fungi: Candida albicans, Aspergillus niger, Aspergillus fumigatus, } \\
\text { Trichophyton rubrum, T. mentagrophytes }\end{array}$ & {$[75,76]$} \\
\hline 2 & (S)-dehydrocurvularin & fungi Curvularia sp. & Fungi: Phytophthora capsici & [21] \\
\hline 3 & 11-hydroxycurvularin & actinomycete Pseudonocardia sp. & Bacteria: Escherichia coli & [24] \\
\hline 4 & 13-Deoxytedanolide & sponge Mycale adhaerens & Fungi: Saccharomyces cerevisiae & [59] \\
\hline 5 & $15 \mathrm{G} 256 \mathrm{w}$ & fungus Hypoxylon oceanicum & Fungi: Neurospora crassa & {$[60,61]$} \\
\hline 6 & 15G256l & fungus Hypoxylon oceanicum & Fungi: Neurospora crassa & {$[60,61]$} \\
\hline 7 & 19-O-demethylscytophycin C & algae Scytonema mirabile, S. burmanicum, S. ocellatum & $\begin{array}{c}\text { Fungi: Aspergillus oryzae, Candida albicans, Penicillium notatum, } \\
\text { Saccharomyces cerevisiae }\end{array}$ & {$[68]$} \\
\hline 8 & 5-hydroxy-de-O-methyllasiodiplodin & fungus No. ZZF36 & Bacteria: Staphylococcus aureus & {$[38]$} \\
\hline 9 & 6-hydroxyscytophycin B & $\begin{array}{c}\text { algae Cylindrospermum muscicola, Scytonema mirabile, } \\
\text { S. burmanicum, S. ocellatum }\end{array}$ & $\begin{array}{c}\text { Fungi: Aspergillus oryzae, Candida albicans, Penicillium notatum, } \\
\text { Saccharomyces cerevisiae }\end{array}$ & {$[67,68]$} \\
\hline 10 & 7-O-malonylmacrolactin A & bacteria Bacillus subtilis & $\begin{array}{c}\text { Bacteria: Staphylococcus aureus, Enterococcus sp., Burkholderia cepacia; } \\
\text { Fungi: Candida crusei }\end{array}$ & {$[79,80]$} \\
\hline 11 & 7-O-succinylmacrolactin A and $\mathrm{F}$ & bacteria Bacillus sp. & Bacteria: Bacillus subtilis, Staphylococcus aureus & [78] \\
\hline 12 & 8'-hydroxyzearalanone & fungi Penicillium sp. & Fungi: Pyricularia oryzae & {$[45,47]$} \\
\hline 13 & Amantelide A & cyanobacterium from family Oscillatoriales & $\begin{array}{l}\text { Bacteria: Staphylococcus aureus, Pseudomonas aeruginosa; } \\
\text { Fungi: Dendryphiella salina, Lindra thalassiae, Fusarium sp. }\end{array}$ & [99] \\
\hline 14 & Amantelide B & cyanobacterium from family Oscillatoriales & Fungi: Dendryphiella salina & [99] \\
\hline 15 & Amphidinolide Q & dinoflagellate Amphidinium sp. & $\begin{array}{c}\text { Bacteria: Staphylococcus aureus, Bacillus subtilis, Escherichia coli; } \\
\text { Fungi: Candida albicans }\end{array}$ & [35] \\
\hline 16 & $\begin{array}{c}\text { Aryl-crowned } \\
\text { polyketide macrolactin }\end{array}$ & bacterium Bacillus subtilis & $\begin{array}{c}\text { Bacteria: Escherichia coli, Aeromonas hydrophilla, Pseudomonas aeruginosa, } \\
\text { Klebsiella pneumoniae, Vibrio sp. }\end{array}$ & [87] \\
\hline 17 & Azalomycin $\mathrm{F}$ analogs & bacteria Streptomyces sp. & $\begin{array}{c}\text { Bacteria: Staphylococcus aureus, Bacillus subtilis, Escherichia coli; } \\
\text { Fungi: Candida albicans }\end{array}$ & {$[94,95]$} \\
\hline 18 & Bahamaolide A & actinomycete Streptomyces sp. & $\begin{array}{c}\text { Fungi: Candida albicans, Aspergillus fumigatus, Trichophyton rubrum, } \\
\text { T. mentagrophytes }\end{array}$ & [95] \\
\hline 19 & Borrelidin & actinomycete Nocardiopsis sp. & $\begin{array}{l}\text { Bacteria: Enterococcus faecalis, E. faecium, Proteus hauseri, Klebsiella pneumoniae, } \\
\text { Salmonella enterica }\end{array}$ & [53] \\
\hline 20 & Borrelidins C and D & actinomycete Nocardiopsis sp. & Bacteria: Salmonella enterica & [55] \\
\hline 21 & Bromophycolides P and Q & alga Callophycus serratus & Bacteria: Staphylococcus aureus, Enterococcus faecium & {$[50]$} \\
\hline 22 & Butremycin & bacteria Micromonospora sp. & Bacteria: Staphylococcus aureus; Escherichia coli & [49] \\
\hline 23 & Chalcomycins A and B & bacteria Streptomyces sp. & Bacteria: Staphylococcus aureus, Bacillus subtilis, Escherichia coli & {$[51,52]$} \\
\hline
\end{tabular}


Table 1. Cont.

\begin{tabular}{|c|c|c|c|c|}
\hline No. & Macrolide & Source & Target & References \\
\hline 24 & Curvularin & fungi Curvularia sp., Eupenicillium sp. & $\begin{array}{c}\text { Bacteria: Bacillus subtilis; Fungi: Phytophthora capsici, Saccharomyces cerevisiae, } \\
\text { Sclerotinia sclerotiorum }\end{array}$ & {$[21,25]$} \\
\hline 25 & Dendrodolides A, C and M & fungi Cladosporium sp. & $\begin{array}{c}\text { Bacteria: Bacillus cereus, Tetragenococcus halophilus, Staphylococcus epidermidis, } \\
\text { Staphylococcus aureus, Escherichia coli, Pseudomonas putida, Nocardia brasiliensis, } \\
\text { Vibrio parahaemolyticus }\end{array}$ & {$[36]$} \\
\hline 26 & de-O-methyllasiodiplodin & fungus No. ZZF36 & $\begin{array}{l}\text { Bacteria: Staphylococcus aureus, Bacillus subtilis, Salmonella enteritidis; } \\
\text { Fungi: Candida albicans, Fusarium oxysporum f.sp. cubense }\end{array}$ & [38] \\
\hline 27 & Dihydrochalcomycin & bacteria Streptomyces sp. & Bacteria: Staphylococcus aureus & [52] \\
\hline 28 & Dihydrohalichondramide & sponge Halichondria sp. & Fungi: Candida albicans & {$[74]$} \\
\hline 29 & Gageomacrolactins & bacterium Bacillus subtilis & $\begin{array}{l}\text { Bacteria: Staphylococcus aureus, Bacillus subtilis, B. cereus, Escherichia coli, } \\
\text { Salmonella typhi, Pseudomonas aeruginosa; Fungi: Aspergillus niger, Botrytis } \\
\text { cinerea, Colletotrichum acutatum, Candida albicans, Rhizoctonia solani }\end{array}$ & [71] \\
\hline 30 & Halichondramide & sponge Halichondria sp. & $\begin{array}{c}\text { Fungi: Candida albicans, Trichophyton mentagrophytes, Aspergillus fumigatus, } \\
\text { Trichophyton rubrum, T. mentagrophytes }\end{array}$ & {$[73,76]$} \\
\hline 31 & Isohalichondramide & sponge Halichondria sp. & Fungi: Candida albicans & [74] \\
\hline 32 & Kabiramide C & unidentified nudibranch & $\begin{array}{c}\text { Fungi: Candida albicans, Aspergillus niger, Penicillium citrium, } \\
\text { Trichophyton interdigitae }\end{array}$ & {$[64]$} \\
\hline 33 & Lasiodiplodin & fungus No. ZZF36 & Bacteria: Staphylococcus aureus, Bacillus subtilis; Fungi: Fusarium oxysporum & [38] \\
\hline 35 & Lobophorin A & bacteria actinomycete & Bacteria: Bacillus thuringensis & {$[41,43]$} \\
\hline 36 & Lobophorin B & bacteria actinomycete & Bacteria: Bacillus thuringensis, Bacillus subtilis & {$[41,44]$} \\
\hline 37 & Lobophorin E & bacteria Streptomyces sp. & Bacteria: Bacillus thuringensis, Bacillus subtilis & {$[43,44]$} \\
\hline 38 & Lobophorin F & bacteria Streptomyces sp. & $\begin{array}{c}\text { Bacteria: Bacillus thuringensis, Bacillus subtilis, Staphylococcus aureus, } \\
\text { Enterococcus faecalis }\end{array}$ & {$[43,44]$} \\
\hline 39 & Lobophorin $\mathrm{H}$ & bacteria Streptomyces sp. & Bacteria: Bacillus subtilis, Staphylococcus aureus & [44] \\
\hline 40 & Lobophorin I & bacteria Streptomyces sp. & Bacteria: Bacillus subtilis & [44] \\
\hline 41 & Macrolactin A & bacteria Bacillus sp., B. subtilis, B. marinus & $\begin{array}{c}\text { Bacteria: Staphylococcus aureus, Bacillus subtilis, Escherichia coli; Fungi: } \\
\text { Aspergillus niger, Botrytis cinerea, Colletotrichum acutatum, Candida albicans, } \\
\text { Rhizoctonia solani }\end{array}$ & {$[71,77,82,83]$} \\
\hline 42 & Macrolactin B & bacteria Bacillus subtilis, B. marinus & $\begin{array}{c}\text { Bacteria: Staphylococcus aureus, Escherichia coli; Fungi: Aspergillus niger, Botrytis } \\
\text { cinerea, Colletotrichum acutatum, Candida albicans, Rhizoctonia solani, Pyricularia } \\
\text { oryzae, Alternaria solani }\end{array}$ & {$[71,82,83]$} \\
\hline 43 & Macrolactin D & bacterium Bacillus marinus & Bacteria: Staphylococcus aureus; Fungi: Pyricularia oryzae, Alternaria solani & [83] \\
\hline
\end{tabular}


Table 1. Cont.

\begin{tabular}{|c|c|c|c|c|}
\hline No. & Macrolide & Source & Target & References \\
\hline 44 & Macrolactin F & bacteria Bacillus sp., B. subtilis & $\begin{array}{l}\text { Bacteria: Staphylococcus aureus, Bacillus subtilis; Fungi: Aspergillus niger, Botrytis } \\
\text { cinerea, Colletotrichum acutatum, Candida albicans, and Rhizoctonia solani }\end{array}$ & {$[71,77,78]$} \\
\hline 45 & Macrolactin K & bacteria Bacillus sp. & Bacteria: Staphylococcus aureus, Bacillus subtilis & [77] \\
\hline 46 & Macrolactin N & bacteria Bacillus subtilis & Bacteria: Escherichia coli, Staphylococcus aureus, Bacillus subtilis & [81] \\
\hline 47 & Macrolactin S & bacteria Bacillus sp., B. marinus, B. amyloliquefaciens & Bacteria: Escherichia coli, Bacillus subtilis, Staphylococcus aureus & [82-84] \\
\hline 48 & Macrolactin V & bacterium Bacillus amyloliquefaciens & Bacteria: Escherichia coli, Bacillus subtilis, Staphyloccocus aureus & [84] \\
\hline 49 & Macrolactin W & bacteria Bacillus sp., B. subtilis & $\begin{array}{c}\text { Bacteria: Bacillus subtilis, Staphylococcus aureus, Escherichia coli, } \\
\text { Pseudomonas aeruginosa; } \\
\text { Fungi: Aspergillus niger, Botrytis cinerea, Colletotrichum acutatum, } \\
\text { Candida albicans, Rhizoctonia solani }\end{array}$ & {$[71,85]$} \\
\hline 50 & Macrolactins G, H, I, J, L and M & bacteria Bacillus sp. & Bacteria: Staphylococcus aureus, Bacillus subtilis & [77] \\
\hline 51 & Maduralide & bacteria actinomycete & Bacteria: Bacillus subtilis & [88] \\
\hline 52 & Marinisporolides A and B & actinomycete Marinispora sp. & Fungi: Candida albicans & [93] \\
\hline 53 & Misakinolide A & sponge Theonella sp. & Fungi: Candida albicans & [62] \\
\hline 54 & Modiolide A & fungi Paraphaeosphaeria sp., Curvularia sp. & $\begin{array}{c}\text { Bacteria: Micrococcus luteus, Staphylococcus aureus; Fungi: Neurospora crassa, } \\
\text { Phytophthora capsici, Microsporum gypseum }\end{array}$ & {$[21,26,27]$} \\
\hline 55 & Modiolide B & fungi Paraphaeosphaeria sp. & Bacteria: Micrococcus luteus; Fungi: Neurospora crassa & [27] \\
\hline 57 & Neomaclafungins A-I & bacteria Actinoalloteichus sp. & Fungi: Trichophyton mentagrophytes & [89] \\
\hline 58 & Neurymenolide A & alga Neurymenia fraxinifolia & Bacteria: Staphylococcus aureus, Enterococcus faecium & [53] \\
\hline 59 & Phomolide A & fungi Phomopsis sp. & Bacteria: Escherichia coli; Fungi: Candida albicans, Saccharomyces cerevisiae & {$[28]$} \\
\hline 60 & Phomolide B & fungi Phomopsis sp. & Bacteria: Escherichia coli; Fungi: Candida albicans, Saccharomyces cerevisiae & {$[28]$} \\
\hline 61 & Phorboxazoles A and B & sponge Phorbas sp. & Fungi: Candida albicans, Saccharomyces carlsbergensis & [90] \\
\hline 62 & PM100117 & bacterium Streptomyces caniferus & Fungi: Candida albicans, Saccharomyces cerevisiae & {$[97,98]$} \\
\hline 63 & PM100118 & bacterium Streptomyces caniferus & Fungi: Candida albicans & [97] \\
\hline 64 & Reedsmycins A-E & bacteria Streptomyces sp., S. youssoufiensis & Fungi: Candida albicans & {$[91,92]$} \\
\hline 65 & Scytophycins & $\begin{array}{l}\text { algae Scytonema sp., S. pseudohofmanni, Cylindrospermum } \\
\text { muscicola, Anabaena sp., Nostoc sp. }\end{array}$ & Fungi: Candida albicans, Aspergillus flavus & {$[66,67,71]$} \\
\hline 66 & Secohalichondramide & sponge Chondrosia corticata & Fungi: Candida albicans, Aspergillus niger & [75] \\
\hline 67 & Spongistatin 1 & porifera Spongia sp., Hyrtios erecta & $\begin{array}{l}\text { Fungi: Candida albicans, Cryptococcus neoformans, Issatchenkia orientalis, } \\
\text { Rhodotorula mucilaginosa, Aspergillus fumigatus, Rhizopus oligosporus }\end{array}$ & {$[100,101,104]$} \\
\hline
\end{tabular}


Table 1. Cont.

\begin{tabular}{|c|c|c|c|c|}
\hline No. & Macrolide & Source & Target & References \\
\hline 68 & Spongistatins 2-7 & porifera Hyrtios erecta, Spirastrella spinispirulifera & Fungi: Candida albicans, Cryptococcus neoformans & [101-104] \\
\hline 69 & Sporiolide A & fungi Cladosporium sp. & $\begin{array}{c}\text { Bacteria: Micrococcus luteus; Fungi: Aspergillus niger, Candida albicans, } \\
\text { Cryptococcus neoformans, Neurospora crassa }\end{array}$ & [39] \\
\hline 70 & Sporiolide B & fungi Cladosporium sp. & Bacteria: Micrococcus luteus & [39] \\
\hline 71 & $\begin{array}{l}\text { Tolytoxin } \\
\text { (6-hydroxy-7-O-methylscytophycin B) }\end{array}$ & $\begin{array}{c}\text { algae Cylindrospermum muscicola, Scytonema mirabile, } \\
\text { S. burmanicum, S. ocellatum, Tolypothrix conglutinata } \\
\text { var. colorata }\end{array}$ & $\begin{array}{l}\text { Fungi: Aspergillus oryzae, Candida albicans, Penicillium notatum, Saccharomyces } \\
\text { cerevisiae Alternaria alternata, Bipolaris incurvata, Calonectria critalarae, } \\
\text { Colletotrichum coccodes, Phyllosticta capitalensis, Phytophtora nicotianae, } \\
\text { Rhizoctonia solani, Sclerotium rofsii, Thielaviopsis paradoxa. } \\
\text { Trichophyton mentagrophytes } \\
\end{array}$ & {$[67-69]$} \\
\hline 73 & Zearalanone & fungi Penicillium sp., Fusarium sp. & $\begin{array}{c}\text { Bacteria: Staphylococcus aureus; Fungi: Pyricularia oryzae } \\
\text { Cryptococcus neoformans }\end{array}$ & {$[45,47,48]$} \\
\hline 74 & $\alpha \beta$-dehydrocurvularin & fungi Eupenicillium sp. & $\begin{array}{c}\text { Bacteria: Bacillus subtilis, Staphylococcus aureus; Fungi: Saccharomyces cerevisiae, } \\
\text { Sclerotinia sclerotiorum }\end{array}$ & [25] \\
\hline
\end{tabular}




\section{Conclusions}

Marine organisms produce 34 groups of macrolides with antibacterial and/or antifungal activities. Among seventy-six antibiotics or their analog sets summarized in the Table, 36 are produced by bacteria, 18 by fungi, ten by sponges, seven by algae, two by porifera and one by nudibranch. At the same time, 29 macrolides or their groups have antifungal activity, 25 have antibacterial, and 20 have both antifungal and antibacterial. Summarizing, marine organisms are abundant in natural macrolides, which may be used in the future for the treatment of bacterial and fungal infections. Marine macrolides can also be potential drugs applicable against pathogens resistant to currently known antibiotics, which is also presented in other papers [105-107].

Funding: This research received no external funding. The APC was partially funded from the budget of the Prof. Michał Nowicki, MD, PhD - Vice-Rector for Science and University Development, Poznań University of Medical Sciences, Poland.

Conflicts of Interest: The author declares no conflict of interest.

\section{References}

1. Burja, A.M.; Banaigs, B.; Abou-Mansour, E.; Burgess, J.G.; Wright, P.C. Marine cyanobacteria - a prolific source of natural products. Tetrahedron 2001, 57, 9347-9377. [CrossRef]

2. El-Demerdash, A.; Tammam, M.A.; Atanasov, A.G.; Hooper, J.N.A.; Al-Mourabit, A.; Kijjoa, A. Chemistry and biological activities of the marine sponges of the genera Mycale (Arenochalina), Biemna and Clathria. Mar. Drugs 2018, 16, 214. [CrossRef] [PubMed]

3. Wang, M.; Zhang, J.; He, S.; Yan, X. A review study on macrolides isolated from cyanobacteria. Mar. Drugs 2017, 15, 126. [CrossRef]

4. Swain, S.S.; Paidesetty, S.K.; Padhy, R.N. Antibacterial, antifungal and antimycobacterial compounds from cyanobacteria. Biomed. Pharmacother. 2017, 90, 760-776. [CrossRef] [PubMed]

5. Liu, Q.-A.; Zheng, J.-J.; Gu, Y.-C.; Wang, C.-Y.; Shao, C.-L. Chapter 7. The chemistry and bioactivity of macrolides from marine microorganisms. Stud. Nat. Prod. Chem. 2015, 44, 353-401.

6. Jelić, D.; Antolović, R. From erythromycin to azithromycin and new potential ribosome-binding antimicrobials. Antibiotics 2016, 5, 29. [CrossRef] [PubMed]

7. Campoy, S.; Adrio, J.L. Antifungals. Biochem. Pharmacol. 2017, 133, 86-96. [CrossRef] [PubMed]

8. Zuckerman, J.M.; Qamar, F.; Bono, B.R. Review of macrolides (azithromycin, clarithromycin), ketolides (telithromycin) and glycylcyclines (tigecycline). Med. Clin. North Am. 2011, 95, 761-791. [CrossRef]

9. Dinos, G.P. The macrolide antibiotic renaissance. Br. J. Pharmacol. 2017, 174, 2967-2983. [CrossRef]

10. Karpiński, T.M.; Andrzejewska, E.; Eder, P.; Linke, K.; Szkaradkiewicz, A. Evaluation of antimicrobial resistance of Helicobacter pylori in the last 15 years in West Poland. Acta Microbiol. Immunol. Hung. 2015, 62, 287-293. [CrossRef]

11. Bolhuis, M.S.; Panday, P.N.; Pranger, A.D.; Kosterink, J.G.; Alffenaar, J.C. Pharmacokinetic drug interactions of antimicrobial drugs: A systematic review on oxazolidinones, rifamycines, macrolides, fluoroquinolones, and beta-lactams. Pharmaceutics. 2011, 3, 865-913. [CrossRef] [PubMed]

12. Mesa-Arango, A.C.; Scorzoni, L.; Zaragoza, O. It only takes one to do many jobs: Amphotericin B as antifungal and immunomodulatory drug. Front. Microbiol. 2012, 3, 286. [CrossRef] [PubMed]

13. OECD. Antimicrobial Resistance. Policy Insights. 2016. Available online: https://www.oecd.org/health/ health-systems/AMR-Policy-Insights-November2016.pdf (accessed on 24 January 2019).

14. Alekshun, M.N.; Levy, S.B. Molecular mechanisms of antibacterial multidrug resistance. Cell 2007, 128, 1037-1050. [CrossRef]

15. Sanjit Singh, A.; Lekshmi, M.; Prakasan, S.; Nayak, B.B.; Kumar, S. Multiple antibiotic-resistant, extended spectrum- $\beta$-lactamase (ESBL)-producing enterobacteria in fresh seafood. Microorganisms 2017, 5, 53. [CrossRef] [PubMed]

16. Gomaa, F.A.M.; Helal, Z.H.; Khan, M.I. High prevalence of blaNDM-1, blaVIM, qacE, and qacE $\Delta 1$ genes and their association with decreased susceptibility to antibiotics and common hospital biocides in clinical isolates of Acinetobacter baumannii. Microorganisms 2017, 5, 18. [CrossRef] [PubMed] 
17. Jayarao, B.; Almeida, R.; Oliver, S.P. Antimicrobial resistance on dairy farms. Foodborne Pathog. Dis. 2019, 16, 1-4. [CrossRef] [PubMed]

18. Florez-Cuadrado, D.; Moreno, M.A.; Ugarte-Ruíz, M.; Domínguez, L. Antimicrobial resistance in the food chain in the European Union. Adv. Food Nutr. Res. 2018, 86, 115-136. [PubMed]

19. Bernd, S.; Kunz, O. Bidirectional cross metathesis and ring-closing metathesis/ring opening of a C2-symmetric building block: A strategy for the synthesis of decanolide natural products. Beilstein, J. Org. Chem. 2013, 9, 2544-2555.

20. Greve, H.; Schupp, P.J.; Eguereva, E.; Kehraus, S.; König, G.M. Ten-membered lactones from the marine-derived fungus Curvularia sp. J. Nat. Prod. 2008, 71, 1651-1653. [CrossRef]

21. Mondol, M.A.; Farthouse, J.; Islam, M.T.; Schüffler, A.; Laatsch, H. Metabolites from the endophytic fungus Curvularia sp. M12 act as motility inhibitors against Phytophthora capsici zoospores. J. Nat. Prod. 2017, 80, 347-355. [CrossRef]

22. Ha, T.M.; Ko, W.; Lee, S.J.; Kim, Y.C.; Son, J.Y.; Sohn, J.H.; Yim, J.H.; Oh, H. Anti-inflammatory effects of curvularin-type metabolites from a marine-derived fungal strain Penicillium sp. SF-5859 in lipopolysaccharide-induced RAW264.7 macrophages. Mar. Drugs 2017, 15, 282. [CrossRef]

23. Greve, H.; Schupp, P.J.; Eguereva, E.; Kehraus, S.; Kelter, G.; Maier, A.; Fiebig, H.H.; König, G.M. Apralactone A and a new stereochemical class of curvularins from the marine-derived fungus Curvularia sp. Eur. J. Org. Chem. 2008, 2008, 5085-5092. [CrossRef]

24. Ye, X.; Anjum, K.; Song, T.; Wang, W.; Yu, S.; Huang, H.; Lian, X.Y.; Zhang, Z. A new curvularin glycoside and its cytotoxic and antibacterial analogues from marine actinomycete Pseudonocardia sp. HS7. Nat. Prod. Res. 2016, 30, 1156-1161. [CrossRef]

25. Xie, L.W.; Ouyang, Y.C.; Zou, K.; Wang, G.H.; Chen, M.J.; Sun, H.M.; Dai, S.K.; Li, X. Isolation and difference in anti-Staphylococcus aureus bioactivity of curvularin derivates from fungus Eupenicillium sp. Appl. Biochem. Biotechnol. 2009, 159, 284-293. [CrossRef]

26. Trisuwan, K.; Rukachaisirikul, V.; Phongpaichit, S.; Preedanon, S.; Sakayaroj, J. Modiolide and pyrone derivatives from the sea fan-derived fungus Curvularia sp. PSU-F22. Arch. Pharm. Res. 2011, 34, 709-714. [CrossRef] [PubMed]

27. Tsuda, M.; Mugishima, T.; Komatsu, K.; Sone, T.; Tanaka, M.; Mikami, Y.; Kobayashi, J. Modiolides A and B, two new 10-membered macrolides from a marine-derived fungus. J. Nat. Prod. 2003, 66, 412-415. [CrossRef]

28. Du, X.; Lu, C.; Li, Y.; Zheng, Z.; Su, W.; Shen, Y. Three new antimicrobial metabolites of Phomopsis sp. J. Antibiot. (Tokyo) 2008, 61, 250-253. [CrossRef] [PubMed]

29. Mohapatra, D.K.; Reddy, D.P.; Dash, U.; Yadav, J.S. Total synthesis of Z-isomer of phomolide B. Tetrahedron Lett. 2011, 52, 151-154. [CrossRef]

30. Lin, X.; Lu, C.-H.; Shen, Y.-M. One new ten-membered lactone from Phomopsis sp. B27, an endophytic fungus of Annona squamosa. Chin. J. Nat. Med. 2008, 6, 391-394. [CrossRef]

31. Ito, A.; Maeda, H.; Tonouchi, A.; Hashimoto, M. Relative and absolute structure of phomolide C. Biosci. Biotechnol. Biochem. 2015, 79, 1067-1069. [CrossRef] [PubMed]

32. Edrada, R.A.; Heubes, M.; Brauers, G.; Wray, V.; Berg, A.; Gräfe, U.; Wohlfarth, M.; Mühlbacher, J.; Schaumann, K.; Bringmann, G.; et al. Online analysis of xestodecalactones A-C, novel bioactive metabolites from the fungus Penicillium of montanense and their subsequent isolation from the sponge Xestospongia exigua. J. Nat. Prod. 2002, 65, 1598-1604. [CrossRef] [PubMed]

33. Liang, Q.; Zhang, J.; Quan, W.; Sun, Y.; She, X.; Pan, X. The first asymmetric total syntheses and determination of absolute configurations of xestodecalactones B and C. J. Org. Chem. 2007, 72, 2694-2697. [CrossRef]

34. Ebrahim, W.; Aly, A.H.; Mándi, A.; Totzke, F.; Kubbutat, M.H.G.; Wray, V.; Lin, W.-H.; Dai, H.; Proksch, P.; Kurtán, T.; et al. Decalactone derivatives from Corynespora cassiicola, an endophytic fungus of the mangrove plant Laguncularia racemosa. Eur. J. Org. Chem. 2012, 18, 3476-3484. [CrossRef]

35. Kubota, T.; Iwai, T.; Sakai, K.; Gonoi, T.; Kobayashi, J. Amphidinins C-F, amphidinolide Q analogues from marine dinoflagellate Amphidinium sp. Org. Lett. 2014, 16, 5624-5627. [CrossRef] [PubMed]

36. Cao, F.; Yang, Q.; Shao, C.L.; Kong, C.J.; Zheng, J.J.; Liu, Y.F.; Wang, C.Y. Bioactive 7-oxabicyclic[6.3.0]lactam and 12-membered macrolides from a gorgonian-derived Cladosporium sp. fungus. Mar. Drugs 2015, 13, 4171-4178. [CrossRef] 
37. Xu, J.; Jiang, C.S.; Zhang, Z.L.; Ma, W.Q.; Guo, Y.W. Recent progress regarding the bioactivities, biosynthesis and synthesis of naturally occurring resorcinolic macrolides. Acta Pharmacol. Sin. 2014, 35, 316-330. [CrossRef] [PubMed]

38. Yang, R.Y.; Li, C.Y.; Lin, Y.C.; Peng, G.T.; She, Z.G.; Zhou, S.N. Lactones from a brown alga endophytic fungus (No. ZZF36) from the South China Sea and their antimicrobial activities. Bioorg. Med. Chem. Lett. 2006, 16, 4205-4208. [CrossRef] [PubMed]

39. Shigemori, H.; Kasai, Y.; Komatsu, K.; Tsuda, M.; Mikami, Y.; Kobayashi, J. Sporiolides A and B, new cytotoxic twelve-membered macrolides from a marine-derived fungus Cladosporium species. Mar. Drugs 2004, 2, 164-169. [CrossRef]

40. Du, Y.; Chen, Q.; Linhardt, R.J. The first total synthesis of sporiolide A. J. Org. Chem. 2006, 71, $8446-8451$. [CrossRef]

41. Jiang, Z.D.; Jensen, P.R.; Fenical, W. Lobophorins A and B, new antiinflammatory macrolides produced by a tropical marine bacterium. Bioorg. Med. Chem. Lett. 1999, 9, 2003-2006. [CrossRef]

42. Li, S.; Xiao, J.; Zhu, Y.; Zhang, G.; Yang, C.; Zhang, H.; Ma, L.; Zhang, C. Dissecting glycosylation steps in lobophorin biosynthesis implies an iterative glycosyltransferase. Org. Lett. 2013, 15, 1374-1377. [CrossRef]

43. Niu, S.; Li, S.; Chen, Y.; Tian, X.; Zhang, H.; Zhang, G.; Zhang, W.; Yang, X.; Zhang, S.; Ju, J.; et al. Lobophorins $\mathrm{E}$ and F, new spirotetronate antibiotics from a South China Sea-derived Streptomyces sp. SCSIO 01127. J. Antibiot. (Tokyo) 2011, 64, 711-716. [CrossRef] [PubMed]

44. Pan, H.Q.; Zhang, S.Y.; Wang, N.; Li, Z.L.; Hua, H.M.; Hu, J.C.; Wang, S.J. New spirotetronate antibiotics, lobophorins H and I, from a South China Sea-derived Streptomyces sp. 12A35. Mar. Drugs 2013, 11, 3891-3901. [CrossRef] [PubMed]

45. Yang, X.; Khong, T.T.; Chen, L.; Choi, H.D.; Kang, J.S.; Son, B.W. 8'-Hydroxyzearalanone and 2'-hydroxyzearalanol: Resorcyclic acid lactone derivatives from the marine-derived fungus Penicillium $\mathrm{sp}$. Chem. Pharm. Bull (Tokyo) 2008, 56, 1355-1356. [CrossRef] [PubMed]

46. Hitchcock, S.A.; Pattenden, G. Synthesis of macrocycles via allylic radical intermediates. A total synthesis of (-)-zearalenone. Tetrahedron Lett. 1990, 31, 3641-3644. [CrossRef]

47. Zhao, L.L.; Gai, Y.; Kobayashi, H.; Hu, C.Q.; Zhang, H.P. 5'-Hydroxyzearalenol, a new $\beta$-resorcylic macrolide from Fusarium sp. 05ABR26. Chin. Chem. Lett. 2008, 19, 1089-1092. [CrossRef]

48. Arunpanichlert, J.; Rukachaisirikul, V.; Sukpondma, Y.; Phongpaichit, S.; Supaphon, O.; Sakayaroj, J. A $\beta$-resorcylic macrolide from the seagrass-derived fungus Fusarium sp. PSU-ES73. Arch. Pharm. Res. 2011, 34, 1633-1637. [CrossRef] [PubMed]

49. Lane, A.L.; Stout, E.P.; Lin, A.S.; Prudhomme, J.; Le Roch, K.; Fairchild, C.R.; Franzblau, S.G.; Hay, M.E.; Aalbersberg, W.; Kubanek, J. Antimalarial bromophycolides J-Q from the Fijian red alga Callophycus serratus. J. Org. Chem. 2009, 74, 2736-2742. [CrossRef] [PubMed]

50. Kyeremeh, K.; Acquah, K.S.; Sazak, A.; Houssen, W.; Tabudravu, J.; Deng, H.; Jaspars, M. Butremycin, the 3-hydroxyl derivative of ikarugamycin and a protonated aromatic tautomer of 5 '-methylthioinosine from a Ghanaian Micromonospora sp. K310. Mar. Drugs 2014, 12, 999-1012. [CrossRef]

51. Asolkar, R.N.; Maskey, R.P.; Helmke, E.; Laatsch, H. Chalcomycin B, a new macrolide antibiotic from the marine isolate Streptomyces sp. B7064. J. Antibiot. (Tokyo) 2002, 55, 893-898. [CrossRef]

52. Jiang, S.; Zhang, L.; Pei, X.; Deng, F.; Hu, D.; Chen, G.; Wang, C.; Hong, K.; Yao, X.; Gao, A.H. Chalcomycins from marine-derived Streptomyces sp. and their antimicrobial activities. Mar. Drugs 2017, 15, 153. [CrossRef]

53. Stout, E.P.; Hasemeyer, A.P.; Lane, A.L.; Davenport, T.M.; Engel, S.; Hay, M.E.; Fairchild, C.R.; Prudhomme, J.; Le Roch, K.; Aalbersberg, W.; et al. Antibacterial neurymenolides from the Fijian red alga Neurymenia fraxinifolia. Org. Lett. 2009, 11, 225-228. [CrossRef]

54. Motuhi, S.E.; Feizbakhsh, O.; Foll-Josselin, B.; Baratte, B.; Delehouzé, C.; Cousseau, A.; Fant, X.; Bulinski, J.C.; Payri, C.E.; Ruchaud, S.; et al. Neurymenolide A, a novel mitotic spindle poison from the new caledonian rhodophyta Phacelocarpus neurymenioides. Mar. Drugs 2019, 17, 93. [CrossRef]

55. Kim, J.; Shin, D.; Kim, S.H.; Park, W.; Shin, Y.; Kim, W.K.; Lee, S.K.; Oh, K.B.; Shin, J.; Oh, D.C. Borrelidins C-E: New antibacterial macrolides from a saltern-derived halophilic Nocardiopsis sp. Mar. Drugs 2017, 15, 166. [CrossRef]

56. Hunter, T.J.; Zheng, J.; O'Doherty, G.A. Approach to the synthesis of the C1-C11 and C14-C18 portion of leucascandrolide A. Org. Chem. Front. 2016, 3, 1120-1125. [CrossRef] 
57. D'Ambrosio, M.; Guerriero, A.; Pietra, F.; Debitus, C. Leucascandrolide A, a new type of macrolide: The first powerfully bioactive metabolite of calcareous sponges (Leucascandra caveolata, a new genus from the Coral Sea). Helvet. Chim. Acta. 1996, 79, 51-60. [CrossRef]

58. Fusetani, N.; Sugawara, T.; Matsunaga, S. Cytotoxic metabolites of the marine sponge Mycale adhaerens Lambe. J. Org. Chem., 1991, 56, 4971. [CrossRef]

59. Nishimura, S.; Matsunaga, S.; Yoshida, S.; Nakao, Y.; Yokoyama, S.; Fusetani, N. 13-Deoxytedanolide, a marine sponge-derived antitumor macrolide, binds to the $60 \mathrm{~S}$ large ribosomal subunit. Bioorg. Med. Chem., 2005, 13, 449. [CrossRef]

60. Schlingmann, G.; Milne, L.; Williams, D.R.; Carter, G.T. Cell wall active antifungal compounds produced by the marine fungus Hypoxylon oceanicum LL-15G256. II. Isolation and structure determination. J. Antibiot. (Tokyo) 1998, 51, 303-316. [CrossRef]

61. Schlingmann, G.; Milne, L.; Carter, G.T. Isolation and identification of antifungal polyesters from the marine fungus Hypoxylon oceanicum LL-15G256. Tetrahedron. 2002, 58, 6825-6835. [CrossRef]

62. Sakai, R.; Higa, T.; Kashma, Y. Misakinolide-A, an antitumor macrolide from the marine sponge Theonella sp. Chem. Lett. 1986, 1499-1502. [CrossRef]

63. Kato, Y.; Fusetani, N.; Matsunaga, S.; Hashimoto, K.; Sakai, R.; Higa, T.; Kashman, Y. Antitumor macrodiolides isolated from a marine sponge sp.: Structure revision of misakinolide A. Tetrahedron Lett. 1987, 28, 6225-6228. [CrossRef]

64. Matsunaga, S.; Fusetani, N.; Hashimoto, K.; Koseki, K.; Noma, M. Kabiramide C, a novel antifungal macrolide from nudibranch eggmasses. J. Am. Chem. Soc. 1986, 108, 847-849. [CrossRef]

65. Sirirak, T.; Kittiwisut, S.; Janma, C.; Yuenyongsawad, S.; Suwanborirux, K.; Plubrukarn, A. Kabiramides J and $\mathrm{K}$, trisoxazole macrolides from the sponge Pachastrissa nux. J. Nat. Prod. 2011, 74, 1288-1292. [CrossRef]

66. Ishibashi, M.; Moore, R.E.; Patterson, G.M.L. Scytophycins, cytotoxic and antimycotic agents from the cyanophyte Scytonema pseudohofmanni. J. Org. Chem. 1986, 51, 5300-5306. [CrossRef]

67. Jung, J.H.; Moore, R.E.; Patterson, G.M.L. Scytophycins from a blue-green alga belonging to the Nostocaceae. Phytochemistry. 1991, 30, 3615-3616. [CrossRef]

68. Carmeli, S.; Moore, R.E.; Patterson, G.M. Tolytoxin and new scytophycins from three species of Scytonema. J. Nat. Prod. 1990, 53, 1533-1542. [CrossRef] [PubMed]

69. Patterson, G.M.; Carmeli, S. Biological effects of tolytoxin (6-hydroxy-7-O-methyl-scytophycin b), a potent bioactive metabolite from cyanobacteria. Arch. Microbiol. 1992, 157, 406-410. [CrossRef] [PubMed]

70. Shishido, T.K.; Humisto, A.; Jokela, J.; Liu, L.; Wahlsten, M.; Tamrakar, A.; Fewer, D.P.; Permi, P.; Andreote, A.P.; Fiore, M.F.; et al. Antifungal compounds from cyanobacteria. Mar. Drugs 2015, 13, 2124-2140. [CrossRef]

71. Tareq, F.S.; Kim, J.H.; Lee, M.A.; Lee, H.S.; Lee, J.S.; Lee, Y.J.; Shin, H.J. Antimicrobial gageomacrolactins characterized from the fermentation of the marine-derived bacterium Bacillus subtilis under optimum growth conditions. J. Agric. Food Chem. 2013, 61, 3428-3434. [CrossRef]

72. Ciavatta, M.L.; Lefranc, F.; Carbone, M.; Mollo, E.; Gavagnin, M.; Betancourt, T.; Dasari, R.; Kornienko, A.; Kiss, R. Marine mollusk-derived agents with antiproliferative activity as promising anticancer agents to overcome chemotherapy resistance. Med. Res. Rev. 2017, 37, 702-801. [CrossRef]

73. Kernan, M.R.; Faulkner, D.J. Halichondramide, an antifungal macrolide from the sponge Halichondria sp. Tetrahedron Lett. 1987, 28, 2809-2812. [CrossRef]

74. Kernan, M.R.; Molinski, T.F.; Faulkner, D.J. Macrocyclic antifungal metabolites from the Spanish dancer nudibranch Hexabranchus sanguineus and sponges of the genus Halichondria. J. Org. Chem. 1988, 53, 5014-5020. [CrossRef]

75. Shin, J.; Lee, H.S.; Kim, J.Y.; Shin, H.J.; Ahn, J.W.; Paul, V.J. New macrolides from the sponge Chondrosia corticata. J. Nat. Prod. 2004, 67, 1889-1892. [CrossRef]

76. Chung, S.C.; Lee, S.H.; Jang, K.H.; Park, W.; Jeon, J.E.; Oh, H.; Shin, J.; Oh, K.B. Actin depolymerizing effect of trisoxazole-containing macrolides. Bioorg. Med. Chem. Lett. 2011, 21, 3198-3201. [CrossRef] [PubMed]

77. Nagao, T.; Adachi, K.; Sakai, M.; Nishijima, M.; Sano, H. Novel macrolactins as antibiotic lactones from a marine bacterium. J. Antibiot. (Tokyo) 2001, 54, 333-339. [CrossRef] [PubMed]

78. Jaruchoktaweechai, C.; Suwanborirux, K.; Tanasupawatt, S.; Kittakoop, P.; Menasveta, P. New macrolactins from a marine Bacillus sp. Sc026. J. Nat. Prod. 2000, 63, 984-986. [CrossRef] [PubMed] 
79. Romero-Tabarez, M.; Jansen, R.; Sylla, M.; Lünsdorf, H.; Häussler, S.; Santosa, D.A.; Timmis, K.N.; Molinari, G. 7-O-malonyl macrolactin A, a new macrolactin antibiotic from Bacillus subtilis active against methicillin-resistant Staphylococcus aureus, vancomycin-resistant enterococci, and a small-colony variant of Burkholderia cepacia. Antimicrob. Agents Chemother. 2006, 50, 1701-1709. [CrossRef]

80. Timmis, K.N.; Molinari, G.; Jansen, R.; Romero-Tabarez, M.; Santosa, D.A. Antibiotic and Method for Production Thereof. EP1791823A1 European Patent Office. Available online: https://patents.google.com/ patent/EP1791823A1/en (accessed on 10 February 2019).

81. Yoo, J.S.; Zheng, C.J.; Lee, S.; Kwak, J.H.; Kim, W.G. Macrolactin N, a new peptide deformylase inhibitor produced by Bacillus subtilis. Bioorg. Med. Chem. Lett. 2006, 16, 4889-4892. [CrossRef] [PubMed]

82. Lu, X.L.; Xu, Q.Z.; Shen, Y.H.; Liu, X.Y.; Jiao, B.H.; Zhang, W.D.; Ni, K.Y. Macrolactin S, a novel macrolactin antibiotic from marine Bacillus sp. Nat. Prod. Res. 2008, 22, 342-347. [CrossRef]

83. Xue, C.; Tian, L.; Xu, M.; Deng, Z.; Lin, W. A new 24-membered lactone and a new polyene delta-lactone from the marine bacterium Bacillus marinus. J. Antibiot. (Tokyo) 2008, 61, 668-674. [CrossRef] [PubMed]

84. Gao, C.H.; Tian, X.P.; Qi, S.H.; Luo, X.M.; Wang, P.; Zhang, S. Antibacterial and antilarval compounds from marine gorgonian-associated bacterium Bacillus amyloliquefaciens SCSIO 00856. J. Antibiot. (Tokyo) 2010, 63, 191-193. [CrossRef] [PubMed]

85. Mondol, M.A.; Kim, J.H.; Lee, H.S.; Lee, Y.J.; Shin, H.J. Macrolactin W, a new antibacterial macrolide from a marine Bacillus sp. Bioorg. Med. Chem. Lett. 2011, 21, 3832-3835. [CrossRef] [PubMed]

86. Mondol, M.A.; Tareq, F.S.; Kim, J.H.; Lee, M.; Lee, H.S.; Lee, Y.J.; Lee, J.S.; Shin, H.J. Cyclic ether-containing macrolactins, antimicrobial 24-membered isomeric macrolactones from a marine Bacillus sp. J. Nat. Prod. 2011, 74, 2582-2587. [CrossRef] [PubMed]

87. Chakraborty, K.; Thilakan, B.; Kizhakkekalam, V.K. Antibacterial aryl-crowned polyketide from Bacillus subtilis associated with seaweed Anthophycus longifolius. J. Appl. Microbiol. 2018, 124, 108-125. [CrossRef]

88. Pathirana, C.; Tapiolas, D.; Jensen, P.R.; Dwight, R.; Fenical, W. Structure determination of maduralide: A new 24-membered ring macrolide glycoside produced by a marine bacterium (actinomycetales). Tetrahedron Lett. 1991, 32, 2323-2326. [CrossRef]

89. Sato, S.; Iwata, F.; Yamada, S.; Katayama, M. Neomaclafungins A-I: Oligomycin-class macrolides from a marine-derived actinomycete. J. Nat. Prod. 2012, 75, 1974-1982. [CrossRef]

90. Searle, P.A.; Molinski, T.F. Phorboxazoles A and B: Potent cytostatic macrolides from marine sponge Phorbas sp. J. Am. Chem. Soc. 1995, 117, 8126-8131. [CrossRef]

91. Yao, T.; Liu, Z.; Li, T.; Zhang, H.; Liu, J.; Li, H.; Che, Q.; Zhu, T.; Li, D.; Li, W. Characterization of the biosynthetic gene cluster of the polyene macrolide antibiotic reedsmycins from a marine-derived Streptomyces strain. Microb. Cell Fact. 2018, 17, 98. [CrossRef]

92. Che, Q.; Li, T.; Liu, X.; Yao, T.; Li, J.; Gu, Q.; Li, D.; Li, W.; Zhu, T. Genome scanning inspired isolation of reedsmycins A-F, polyene-polyol macrolides from Streptomyces sp. CHQ-64. RSC Adv. 2015, 5, 22777-22782. [CrossRef]

93. Kwon, H.C.; Kauffman, C.A.; Jensen, P.R.; Fenical, W. Marinisporolides, polyene-polyol macrolides from a marine actinomycete of the new genus Marinispora. J. Org. Chem. 2009, 74, 675-684. [CrossRef]

94. Yuan, G.; Lin, H.; Wang, C.; Hong, K.; Liu, Y.; Li, J. 1H and 13C assignments of two new macrocyclic lactones isolated from Streptomyces sp. 211726 and revised assignments of azalomycins F3a, F4a and F5a. Magn. Reson. Chem. 2011, 49, 30-37. [CrossRef] [PubMed]

95. Yuan, G.; Hong, K.; Lin, H.; She, Z.; Li, J. New azalomycin F analogs from mangrove Streptomyces sp. 211726 with activity against microbes and cancer cells. Mar. Drugs 2013, 11, 817-829. [CrossRef] [PubMed]

96. Kim, D.G.; Moon, K.; Kim, S.H.; Park, S.H.; Park, S.; Lee, S.K.; Oh, K.B.; Shin, J.; Oh, D.C. Bahamaolides A and $\mathrm{B}$, antifungal polyene polyol macrolides from the marine actinomycete Streptomyces sp. J. Nat. Prod. 2012, 75, 959-967. [CrossRef]

97. Pérez, M.; Schleissner, C.; Fernández, R.; Rodríguez, P.; Reyes, F.; Zuñiga, P.; de la Calle, F.; Cuevas, C. PM100117 and PM100118, new antitumor macrolides produced by a marine Streptomyces caniferus GUA-06-05-006A. J. Antibiot. (Tokyo) 2016, 69, 388-394. [CrossRef] [PubMed]

98. Salcedo, R.G.; Olano, C.; Gómez, C.; Fernández, R.; Braña, A.F.; Méndez, C.; de la Calle, F.; Salas, J.A. Characterization and engineering of the biosynthesis gene cluster for antitumor macrolides PM100117 and PM100118 from a marine actinobacteria: Generation of a novel improved derivative. Microb. Cell Fact. 2016, 15, 44. [CrossRef] 
99. Salvador-Reyes, L.A.; Sneed, J.; Paul, V.J.; Luesch, H. Amantelides A and B, polyhydroxylated macrolides with differential broad-spectrum cytotoxicity from a Guamanian marine cyanobacterium. J. Nat. Prod. 2015, 78, 1957-1962. [CrossRef]

100. Pettit, G.R.; Cichacz, Z.A.; Herald, C.L.; Boyd, M.R.; Schmidt, J.M.; Hooper, J.N.A. Isolation and structure of spongistatin 1. J. Org. Chem. 1993, 58, 1302-1304. [CrossRef]

101. Pettit, G.R.; Cichacz, Z.A.; Gao, F.; Herald, C.L.; Boyd, M.R. Isolation and structure of the remarkable human cancer cell growth inhibitors spongistatins 2 and 3 from an Eastern Indian Ocean Spongia sp. J. Chem. Soc. Chem. Commun. 1993, 14, 1166-1168. [CrossRef]

102. Pettit, G.R.; Herald, C.L.; Cichacz, Z.A.; Gao, F.; Schmidt, J.M.; Boyd, M.R.; Christie, N.D.; Boettner, F.E. Isolation and structure of the powerful human cancer cell growth inhibitors spongistatins 4 and 5 from an African Spirastrella spinispirulifera (Porifera). J. Chem. Soc. Chem. Commun. 1993, 24, 1805-1807. [CrossRef]

103. Pettit, G.R.; Herald, C.L.; Cichacz, Z.A.; Gao, F.; Schmidt, J.M.; Boyd, M.R.; Christie, N.D.; Boettner, F.E. Antineoplastic agents 293. The exceptional human cancer cell growth inhibitors spongistatins 6 and 7. Nat. Prod. Lett. 1993, 3, 239-244. [CrossRef]

104. Pettit, R.K.; McAllister, S.C.; Pettit, G.R.; Herald, C.L.; Johnson, J.M.; Cichacz, Z.A. A broad-spectrum antifungal from the marine sponge Hyrtios erecta. Int. J. Antimicrob. Agents. 1997, 9, 147-152. [CrossRef]

105. Kasanah, N.; Hamann, M.T. Development of antibiotics and the future of marine microorganisms to stem the tide of antibiotic resistance. Curr. Opin. Investig. Drugs. 2004, 5, 827-837.

106. Fair, R.J.; Tor, Y. Antibiotics and bacterial resistance in the 21st century. Perspect. Medicin. Chem. 2014, 6, 25-64. [CrossRef]

107. Abdelmohsen, U.R.; Balasubramanian, S.; Oelschlaeger, T.A.; Grkovic, T.; Pham, N.B.; Quinn, R.J.; Hentschel, U. Potential of marine natural products against drug-resistant fungal, viral, and parasitic infections. Lancet Infect. Dis. 2017, 17, e30-e41. [CrossRef]

(C) 2019 by the author. Licensee MDPI, Basel, Switzerland. This article is an open access article distributed under the terms and conditions of the Creative Commons Attribution (CC BY) license (http://creativecommons.org/licenses/by/4.0/). 